\title{
INSTRUCTION TO OVERCOME THE DIFFICILTY IN ACQUIRING ENGLISH SEGMENTS NON EXISTENT IN KURDISH TO KURDISH EFL LEARNERS
}

\author{
LUREEN I. NASER and REJAN M. HASAN \\ Dept. of English Language, College of Basic Education, University of Duhok, Kurdistan region, Iraq. \\ Dept. of English Language, College of Language, University of Duhok, Kurdistan region, Iraq.
}

\begin{abstract}
In every language, speakers usually have fixed numbers of sound-units which are combined together to form the words of the language. O'Connor (1980) describes this as having a number of fixed boxes for each sound, which we go to when we speak to form words. Every language has different numbers and arrangements of these boxes, which become stronger with time. As a result, when learners try to learn a new language which certainly has different numbers of boxes compared to their native language, they need to build up new boxes for the new sounds. Usually this is not a very easy thing to do unless they have enough exposure to the target language. So, when they find it difficult to build a new box, they replace these sounds with other sounds that are articulately closer to them. For example, they replace the sound with $\quad$ which are both voiceless fricatives and are very common in English. Dental fricatives in English are among the most mispronounced sounds by Kurdish EFL learners. Students will overcome this difficulty after instruction.

The problem with these sounds can either be a perception problem or a production problem. Concerning the velar nasal, learners cannot easily articulate the sound $\therefore \quad$ because their organs of speech are not used to make the movements that produce this sound. Besides, they cannot hear the sound easily and often confuse it with this combination /ng/. For this reason, they lack the skill of predicting its presence or absence in a word.

As for the dental fricatives $\sigma \Omega \Omega^{-1}$ articulation, not only for learners but also for native speakers. The other difficulty of these sounds could be in their perception. Acoustically speaking, these sounds are perceptually weak and are easily confused with labiodental fricatives /f/ or /v/ and can thus be perceptually ambiguous (Jekiel, 2012).

It is hypothesized that Kurdish EFL learners will also face difficulty with these sounds. This difficulty can be overcome with appropriate instruction. Ten participants, who have not received prior instruction in English phonetics and phonology, were chosen for the purpose of the analysis. They were asked to read (15) minimal pairs of each target sound contrasted with similar sounds in a pre-instruction test. They were later asked to read them again in a post-instruction test. After examining the production of these target sounds in both tests, it appears that the number of mispronunciation errors is reduced from $(84 \%)$ to $(14 \%)$ of the data. This reduction in the number of errors is the result of the given instruction. It appears that providing instruction is valuable and efficient in overcoming this difficulty. The results are of value to the teachers who teach Phonetics and Phonology in the English departments. This also proves that teaching Phonetics and Phonology should not be underestimated.
\end{abstract}

KEY WORDS: Kurdish EFL Learners, Error Analysis, pronunciation, English dental fricatives.

\section{INTRODUCTION}

Tn this study, we aim to predict whether certain English sounds that do not exist in Kurdish are problematic for Kurdish EFL learners and find out how they substitute these sounds. Then we offer efficient instruction modes to overcome this difficulty. If we compare the consonants of both Kurdish and English, we can see that they are different. English has certain consonants that do not exist in Kurdish such as dental fricatives 


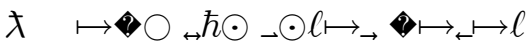

$\therefore \quad$ The two dental fricatives, which are denoted in the English alphabet by (th), differ in voicing. The dental fricatives are highly marked sounds since they are very rare in the world's languages and only occur in $43(7.6 \%)$ out of the 566 languages surveyed (Maddieson, 2013).

These consonants are expected to be problematic for Kurdish EFL learners. When learners come across words in the target language that contain these sounds, they read these words based on their existing knowledge of the phonemes of their first language. So, they modify the production of certain words which contain phonemes that do not exist in their native language. This results in inaccurate pronunciation of foreign language sequences.

\section{AIMS}

This paper aims to achieve the following points: 1. Investigate the learning of dental fricatives $\mapsto \bigcirc \quad \lambda \quad$ and the velar nasal $\therefore \quad$ which are non-existent in Kurdish by Kurdish EFL learners and to what extent they mispronounce these sounds.

2. Examine which sounds act as substitutes of the sounds $\mapsto \diamond \quad \lambda$ and.

3. Try methods of instruction to improve their performance in producing the target sounds, reduce their substitution and suggest pedagogical implications.

\section{THE MODEL}

The model that we followed here is Error Analysis (EA) which is adopted to analyze the errors students make when they pronounce the sounds $\quad \lambda \mapsto \circ \quad . \quad$ which are nonexistent in Kurdish. The systematic errors they make in their production reveal whether they have problems in this aspect or not. Then, the subjects receive instruction to show whether they have developed or not. When errors are examined they show the stage of development in the learner's language. Dulay, et al. (1982) affirm that errors could also be good indicators of the difficult parts of L2 which teachers need to pay attention to.

\section{RELATED LITERATURE}

The main purpose of teaching a language and specially pronunciation is to help students learn to communicate and avoid communication breakdown. In order to achieve this, pronunciation should be intelligible; that is clear enough to be heard and understood. What lays as the foundation for spoken communication is having the ability to pronounce segments correctly in the first place.

In English language there is no one to one correspondence between sounds and letters. The number of sounds (44) is far more then the number of letters (26). In Kurdish on the other hand there is a strong correspondence between sounds and letters. This is why Kurdish EFL learners face difficulty when acquiring the different sounds of English, especially those nonexistent in the Kurdish sound inventory, namely

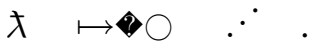
In a contrastive analysis of English and Kurdish, Rahimpour \& Dovaise (2011) notice that Kurdish EFL learners substitute /s/ or /t/ for English

and /z/ or /d/ for English $\lambda$ for example, pronouncing "then" as /den/ and /zen/ by most of the Kurdish students (also see Muhammadi (2014)).

Speakers of other languages, who try to learn English, face the same problem. In a study that investigated the sound production of EFL Indonesian teacher students by Arief \& Hamidiyah, they observed these teacher students in practice and found that they were very challenged with the production of certain English consonant sounds such as $\lambda \quad \rightarrow \quad \varangle \quad$ and

$\succ \quad$ and replaced them with sounds from their own language $/ \mathrm{d} /, / \mathrm{t} /, / \mathrm{p} /, / \mathrm{s} /$ and $/ \mathrm{p} /$ respectively.

Metruk (2017) examines the degree of difficulty in pronouncing English dental fricatives by Slovak EFL learners. $\mathrm{He}$ found that they were mispronounced to a substantial degree. Consonants $/ \mathrm{t} /$ and $/ \mathrm{f} /$ acted as substitutes for $/ \theta /$, while consonants $/ \mathrm{d} / \mathrm{and} / \mathrm{t} /$ were used as a replacement for 
$/ ð /$. He asserts the importance of focusing on proper pronunciation instruction as part of the curriculum to overcome this difficulty.

Osborne (2008) investigates the interlanguage of a Brazilian Portuguese learner of English. He found that she replaces dental fricatives with $/ \mathrm{t} /$ and $/ \mathrm{d} /$ systematically through all her speech since these sounds are not part of her phoneme inventory. This leads to confusion and lack of intelligibility in certain replacement occasions (e.g., thanks $\because{ }^{\cdot} \leftarrow$ and tanks $\because \cdot^{\cdot} \leftarrow$ ).

Karakas (2011) points out that Turkish EFL learners and teachers also face difficulty with the dental fricatives $\mapsto \diamond \quad \lambda$ due to their nonexistence in the Turkish sound inventory. So, they replace these sounds with $/ \mathrm{t} /$ and /d/ respectively.

$\begin{array}{clc}\text { taught } \leftrightarrow / \leftrightarrow & \text { vs. } & \text { thought } \\ \text { dose } \bigcirc_{\|} \cup z & \text { vs. } & \text { those } \\ \| \cup z & & \end{array}$

He therefore suggests that these sounds should be given special attention and provides a lesson plan that teachers can follow to overcome fossilization of these errors.

Nizamuddin (2015) shows that the fricatives of English /f , v , $\theta, \partial z, z /$ do not exist in Hindi. So, they are difficult for acquisition. Some speakers of English in India are able to articulate the phonemes /f/, /v/, /z/ and /3/ in their spoken English. This may be due to the fact that these sounds can be found in languages like Urdu, Arabic and Panjabi which are also spoken in India. So, the speakers might have acquired these sounds from these languages. Whereas, dentals $/ \theta, \delta /$ of English are among the most difficult sounds for them and hence they are missing from Indian English and are replaced with dental plosives.

Many other EFL language learners face the same problem because of the lack of these target sounds in their sound inventory; such as Buginese, which is a language spoken in Indonesia (Nurpahmi, 2013).

Jesney (2005) describes the same problem with French ESL learners. She states that the replacement of target language sounds, especially the marked ones which are uncommon, is systematic and very common among many French EFL learners. The most preferred and common substitutes are /s, z/ and $/ \mathrm{t}, \mathrm{d} /$.

Morrison (2005) also mentions that these French ESL speakers tend to substitute dental fricatives with dental stops. The nature of substitution differs from Canadian-French speakers, who substitute them with dental stops /t/ and /d/, to EuropeanFrench speakers, who substitute them with $/ \mathrm{s} /$ and $\mathrm{l} \mathrm{z} /$. The difference, according to Morrison (ibid), is due to the fact that European-French /s/ tends to be dental; Canadian-French $/ \mathrm{s} /$ is alveolar. For Canadians the dental plosive is the closest L1 sound to the English dental fricative, but for Europeans the strident dental fricative is the closest.

The French language, which is regarded as the source of Cajun variety of English spoken by people of Acadian descent in southern Louisiana, has also affected this variety to the extent that they replace the dental fricatives with $/ \mathrm{t} / \mathrm{and} / \mathrm{d} / \mathrm{in}$ all English words containing these sounds. So, they say 'dis' and 'tink' instead of 'this' and 'think' (Dubois \& Horvath, 1999).

Wester, et al. (2007) state that although Dutch learners have a high level of English, few of them produce target-like production of dental fricatives. They also substitute dental fricatives.

After reviewing the related literature, the frequency of the difficulty in the pronunciation of the target sounds becomes obvious. Research in this area with reference to Kurdish EFL learners has not been investigated so far. This calls for the necessity of conducting a similar research investigating the difficulty of pronouncing the target sounds by Kurdish EFL learners.

\section{- Stimuli (Target words)}

\section{PROCESS}

A list of example pairs that include the target sounds were contrasted with sounds that may act as their substitutes (see Appendix A). was contrasted with $\leftarrow . \lambda$ was contrasted with $\therefore \quad$ was contrasted with $\diamond$

The following are example pairs: 


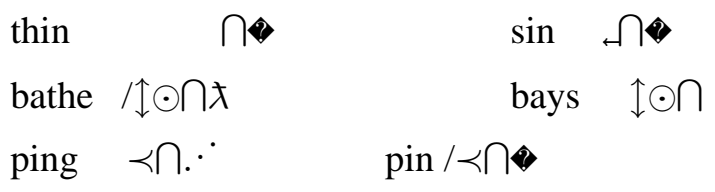

- Subjects

The subjects were (25) Kurdish EFL students from Duhok university/ college of Humanities/ English department/ $1^{\text {st }}$ stage (2016-2017), who have not received instruction in English Phonetics and Phonology as an independent topic in their syllabus.

\section{- Procedures}

It contains a twofold production task. The first task is reading the list of pairs chosen for the purpose of the study before instruction. The second one includes reading the same list after instruction. The purpose of these tasks is to reveal the level progress and the effectiveness of instruction. The readings are recorded on a PC. The recordings are transcribed phonemically using IPA.

\section{- Instruction}

In order to realize the target dental fricatives $\lambda \mapsto \bigcirc \quad$ correctly, learners need to approach their tongue tip towards the upper teeth in a way that allows air to escape through them as Roach (2009) suggested. Concerning the velar nasal $\therefore$, the back of the tongue approaches the velum making a velar closure and allowing the air to escape from the nose. The articulatory movements needed for the production of these sounds are difficult for second language learners since their articulators are not familiar with these movements.

This means that learners try to add new sounds to their existing schemata in a process called accretion as Celce, et al. (1996) suggested. The teaching stages which should be followed in order to introduce new sounds as proposed by them are as follows:

\section{a. Analysis and consciousness raising:}

The diagnosis of the problem is based on typical errors by learners depending on a test on the area of difficulty. The first step of teaching, adopted by the researchers, begins with the description of target sounds as being major phonemes in English. This is done by giving a presentation on the features of these sounds and how they are articulated by the vocal organs, including reference to their place and manner of articulation and their voicing states.

\section{b. Listening discrimination:}

This is done through providing maximum exposure to these target sounds through focused listening practice activities such as audios of minimal pairs from O'Connor (1980), word choice, educational videos of a specialist instructing how the sounds are produced by exemplifying the sounds, and asking them to circle the target sounds in sentences in a listening activity.

Tuan (2010) asserts that minimal pair drills have a very high pedagogical effectiveness when employed as a teaching tool for phoneme discrimination. They create an environment in which sounds are contrasted and perceived with ease which facilitates the acquisition of discrete sounds. This also creates awareness on the importance of being accurate in pronunciation in order to avoid misperception or confusion on the part of the listener.

\section{c. Production:}

This is achieved by providing ample opportunities for students to produce the target sounds through guided reading practice activities accompanied by constant feedback on the part of the researchers. These activities included reading minimal pairs, short dialogues and even communicative practice activities that elicit the use of words that contain these sounds like creating a communicative situation where students are divided into pairs and are handed a collage of pictures of items with the target sounds. Students are assigned the roles of seller-customer to use the target sounds in their dialogues (Celce, et al., 1996)

\section{DISCUSSION}

After analyzing the results of the pre_instruction test, a total of 10 participants (100\%) mispronounced (378) out of (450) of the target consonants $/ \theta /, / ठ /$ and.${ }^{\circ}$ which make up $(84 \%)$ of their data. 
Subjects produced (112) mispronunciations of $/ \theta /$ out of (150) words, which makes up $(75 \%)$ of the data. They also produced (133) mispronunciations for each of /ð/ and $\quad \therefore \quad$ which each make up $(89 \%)$ of their data as shown in table and chart (1).

Table (1) :-Mispronunciation Errors before Instruction

\begin{tabular}{ccc}
\hline & $\lambda$ & $\cdot$ \\
\hline $75 \%$ & $89 \%$ & $89 \%$ \\
\hline Total Errors & 378 & $\mathbf{8 4 \%}$ \\
\hline
\end{tabular}

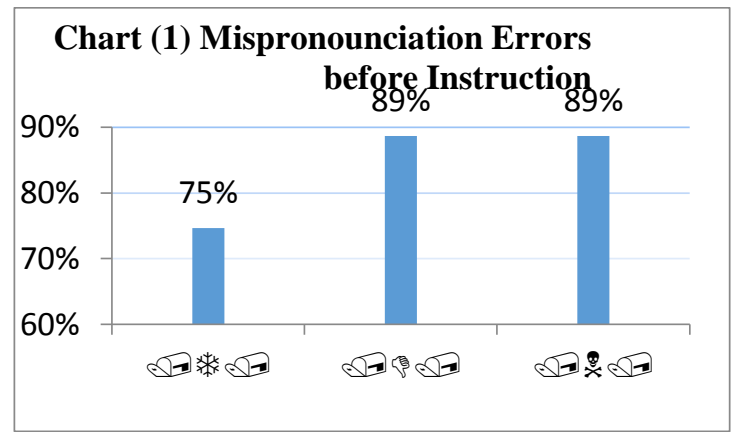

The results of the post instruction test have shown significant changes. After instruction subjects scored lower levels of error. Participants produced (61) mispronunciation errors which make up only (14\%) of the data.

Subjects produced only (6) mispronunciations of $/ \theta /$ out of (150) words, which make up (4\%) of the data. They also produced (30) mispronunciations of /ð/ which make up $(20 \%)$ of their data. They also produced (25) mispronunciation of $\therefore$ which make up $(17 \%)$ of their data as shown in table and chart (2)

Table (2)-: Mispronunciation Errors after Instruction

\begin{tabular}{ccc}
\hline & $\lambda$ & $\therefore$ \\
\hline $4 \%$ & $20 \%$ & $17 \%$ \\
\hline Total Errors & 61 & $\mathbf{1 4 \%}$ \\
\hline
\end{tabular}




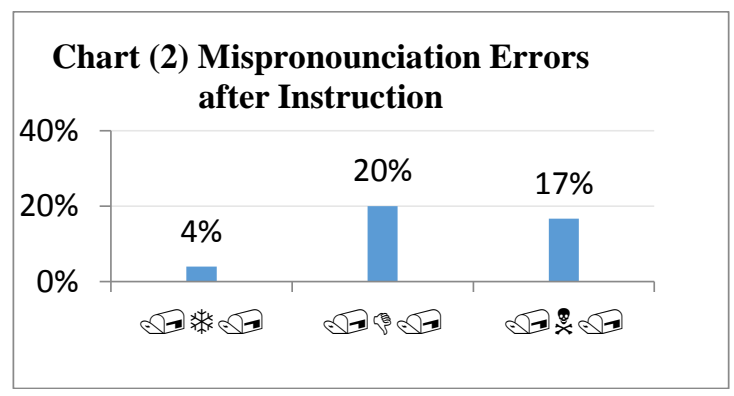

A comparison of both test results shows the in their production as clearly shown in table and significance of instruction in reducing error numbers chart (3).

Table (3):- Total Errors

\begin{tabular}{cc}
\hline Before Instruction & After Instruction \\
\hline 378 & 61 \\
\hline $\mathbf{8 4 \%}$ & $\mathbf{1 4 \%}$ \\
\hline
\end{tabular}

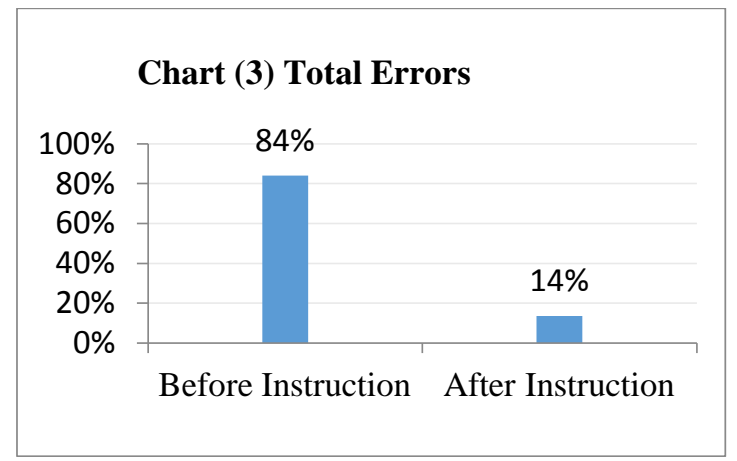

Concerning the target sounds substitutes, participants exhibited a particular pattern regarding the substitutes of the target sounds. Substitutes of

along with their percentages are shown in table and chart (4) bellow:

Table (4) : - $\quad$ substitutes

\begin{tabular}{|c|c|c|c|}
\hline$/ \mathrm{t} /$ & $\mid s /$ & $/ d /$ & $\lambda$ \\
\hline $75 \%$ & $21 \%$ & $2 \%$ & $2 \%$ \\
\hline
\end{tabular}




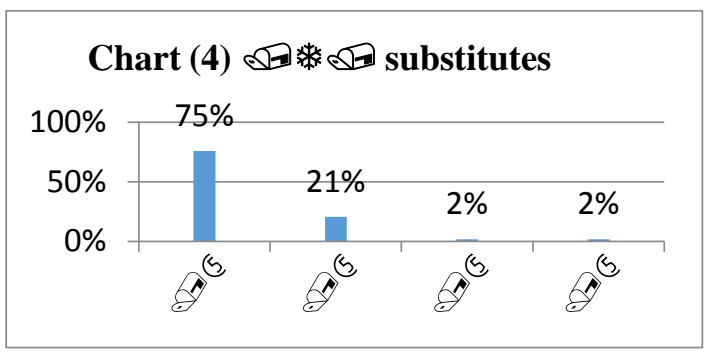

(76\%) of the mispronunciation errors were the ones in which was substituted for / $t /$ such as S2's output in example (1):

(1) S2's output:

\section{Lexical item Output Pronunciation}

think ค. ${ }^{*}$

$$
\cap \cdot \cdot
$$

path

$$
\prec \because \leftrightarrow
$$$$
\prec \square
$$

(21\%) of the mispronunciation errors were the ones in which was substituted for $/ \mathrm{s} / \mathrm{such}$ as example (2):

(2) S5's output:
thank
$\therefore$
$\because$
math
$\mp \stackrel{\wedge}{=}$
$\mp \because$ a few instances such as in examples (3) and (4):

(3) S9's output:

Lexical item Output TP thin

(4) S7's output:

$\begin{array}{lcl}\text { Lexical item } & \text { Output } \\ \text { thin } & \end{array}$

The substitutes of the sound $\lambda$ with their occurrence percentages are shown in table and chart (5) bellow:

\section{Lexical item Output TP}

Table (5): $-\quad \lambda$

substitutes

\begin{tabular}{llllll}
\hline$/ \mathrm{t} /$ & $/ \mathrm{s} /$ & & $/ \mathrm{d} /$ & $/ \mathrm{z} /$ & $/ \mathrm{m} /$ \\
\hline $50 \%$ & $25 \%$ & $17 \%$ & $4 \%$ & $3 \%$ & $1 \%$ \\
\hline
\end{tabular}

Some of these errors, like substituting / $\lambda$ by $\mp \quad$ are may be due to slips of the tongue. 


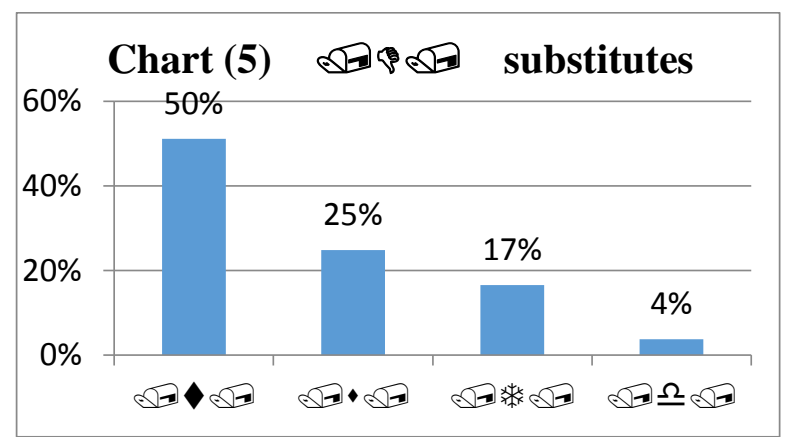

A prevalence of the errors in pronouncing the voiced dental fricative $\lambda$ as /t/ occurred at (50 $\%)$ of the errors, which are exemplified in the following participant performance:

(5) S8's output:

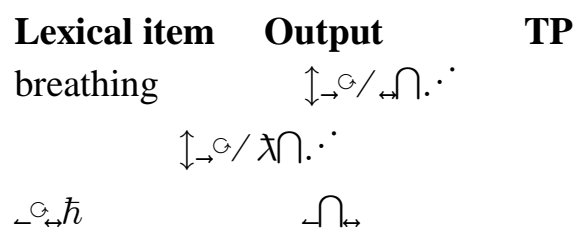

Examples of $/ \mathrm{s} /$ and as substitutes of $\lambda$ were also marked in the participant's performance to a certain degree, such as examples (6) and (7):

(6) S6's output:

\section{$\bigcap \lambda$}

Lexical item Output though $\leftarrow \Perp U$ TP ${ }_{\leftrightarrow} \odot \odot_{\leftrightarrow} \hbar \odot$ $\leftrightarrow^{\circ / \leftarrow}$ $\leftrightarrow^{\sigma / \lambda}$

(7) S9's output:

\section{Lexical item Output}

soothe

$\leftarrow$ o/ $\leftarrow / \lambda$

though

The voiced dental fricative $\lambda$ was also identified as /d/or /z/ to a lesser degree in words such as in examples (8) and (9):

(8) S4's output:

\section{Lexical item Output} then

breath

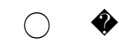

br3z/
TP

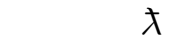

(9) S6's output:
Lexical item Output

$-\sigma_{+} \hbar$

Bathe
$/ \uparrow \because$
TP
The velar nasal $\quad \therefore \quad$ was also substituted with different sounds which are shown in table and chart (6) accompanied with their occurrence percentages: $\bigcap \lambda$

$$
\lambda_{\Perp} \bigcup
$$

\section{$\Perp \Perp$}




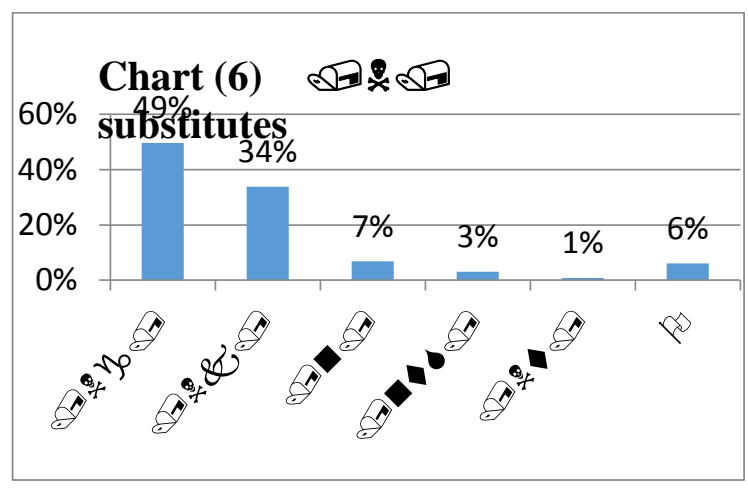

Half of the mispronunciations of the velar nasal were mostly pronounced with a final velar stop/g/ in words such as in example (10):

(10) S6's output:

\section{Lexical item Output

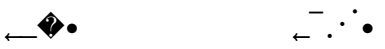

Hanged

$$
\hbar \because \therefore \circ
$$

TP

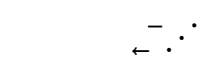

$\hbar \because \cdot{ }^{\circ}$

The velar nasal was also pronounced with a final voiceless velar stop / $\mathrm{k} /$ in (34 \%) of the errors:

(11) S10's output:

\section{Lexical item Output \\ $\mathbf{T P}$ \\ Sing $\quad \cap$. \\ king \\ ก. \\ ก. \\ ก. ${ }^{*}$}

Other substitutes of the velar nasal, which are shown in table and chart (6) are exemplified bellow:

(12) S1's output:

\section{Lexical item Output TP}

Some of the participants used the strategy of avoidance when they faced difficulty in producing the velar nasal $\quad \therefore \quad$ For example, S1 and S7 avoided pronouncing the target sound.${ }^{\circ}$ in their outputs as in examples (15) and (16):

(15) S1's output:

\section{Lexical item Output \\ tongue

$$
\stackrel{\wedge}{=} /
$$

TP

(16) S7's output:

$$
\begin{aligned}
& \text { hanged } \quad \hbar: \diamond \bigcap \\
& \hbar \because{ }^{\circ} \bigcirc
\end{aligned}
$$

(13) S2's output:

$$
\begin{aligned}
& \text { Lexical item Output TP } \\
& \text { ponged } \quad \prec \mapsto \bigcup \vartheta_{\hookleftarrow} \varangle \\
& \prec \rightleftarrows .{ }^{\circ} \bigcirc \\
& \text { hanged } \quad \hbar \because \diamond_{\leftrightarrow} \varangle \bigcap_{\leftrightarrow} \quad \hbar \because \bullet^{\circ} \circ
\end{aligned}
$$

(14) S7's output (which is the only occurrence) :

$\begin{array}{lccc}\text { Lexical item } & \text { Output } & \text { TP } & \\ \text { king } & \cap .{ }_{\leftrightarrow} & & \cap .{ }^{\cdot}\end{array}$

$\begin{array}{lccc}\text { Lexical item } & \text { Output } & \text { TP } & \\ \text { tongue } & \leftrightarrow \mapsto \cup & & -. \cdot \\ \leftrightarrow & & & \end{array}$

\section{CONCLUSIONS}

This research has come up with the following conclusions:

- The participants faced difficulty in pronouncing $\lambda \mapsto \diamond \quad \therefore \quad$ due to their nonexistence in their mother tongue language, Kurdish. This was clear through the high percentage of 
mispronouncing errors they made in the pre-test reading which represent $(84 \%)$ of the data. This high percentage shows the seriousness of the matter in question.

- The results showed the necessity of providing appropriate guidance for the correct pronunciation of the target sounds.

- The participants replaced the three sounds with different substitutes. The most common substitutes of both $\quad \longmapsto \circ / \mathrm{J} /$ were the sounds /t/ and /s/, rated $(75 \%)$ and $(50 \%)$ respectively. These substitutions may be caused by the participants' lack of ability to differentiate between the two readings of the (th) combination. As for the sound $/ . \%$, it was mostly mispronounced as $/ . \therefore /$ which is $(49 \%)$ of the $/ . \because$ substitutes.

- The instruction was helpful in reducing the number of errors to $(14 \%)$, which were clear in the results of the post test. The reduction of errors to this small rate shows the success of the research aim.

- The research also has important pedagogical implications for pronunciation teachers. The effectiveness of instruction conducted in the research shows the importance of teaching pronunciation lessons to Kurdish EFL learners. Appropriate instruction helps to overcome the pronunciation difficulties that learners face. Teaching Phonetics and Phonology as part of the curriculum is essential.

\section{REFERENCES}

-Ali, B. O. (2007). The $\therefore \quad$ Phoneme in Sulaimany dialect (in Kurdish). Sulaimany University Magazine, B. No.19. Pp. 39-46.

-Ameen. N. A. (1982). Kurdish writing problems with reference to vowels and consonant (in Kurdish). The jornal of the Iraqi Academy, Kurdish corporation. Vol. 9. Baghdad: Iraqi assembly press. Pp. 360-419.

-Celce-Murcia, M., Brinton, D. M. \& Goodwin, J.M. (1996). Teaching pronunciation: A reference for teachers of English to speakers of other languages. Cambridge: Cambridge University Press.
-Dubois, S. \& Horvath, B. M. (1999). Let's tink about dat: Interdental fricatives in Cajun English. Language Variation and Change, 10. U.S.A.: Cambridge University Press. Pp. 245-261.

-Dulay, H., Burt, M., \& Krashen, S. (1982). Language two. New York: Oxford University press.

- Jekiel M. (2012). The evolution of English dental fricatives: variation and change. AMU Faculty of English, Poznań, Poland.

-Jesney K. (2005). Stridency and Differential Substitution in Two Dialects of French. Language Research Centre Graduate Student Forum.

-Karkas A. (2011). The teaching of [ ] and [ð] sounds in English. 1st International Conference on Foreign Language Teaching and Applied Linguistics May 5-7. Sarajevo. Pp 74-83.

-Maddieson, Ian. 2013. "Presence of Uncommon Consonants", in: Martin Haspelmath, Matthew S. Dryer (eds.), The World Atlas of Language Structures Online. Leipzig: Max Planck Institute for Evolutionary Anthropology. (Available online at http://wals.info/chapter/19, Accessed on 2017-08-09.)

-Metruk M. (2017). Pronunciation of English dental fricatives by Slovak university EFL students. International Journal of English Linguistics; Vol. 7, No. 3. Canadian Center of Science and Education. Pp. 11-16.

-Morrison, G. S. (2005). Dat is what the PM said: A quantitative analysis of Prime Minister Chrétien's pronunciation of English voiced dental fricatives. Cahiers linguistiques d'Ottawa, 33, 1-21. Ottawa, Ontario: University of Ottawa, Department of Linguistics.

-Muhammadi J. (2014). A survey of Kurdish students' sound segment \& syllabic pattern errors in the course of learning EFL. Advances in Language and Literary Studies. Vol. 5 No. 3. Australia: Australian International Academic Centre. Pp. 18-21.

- Nizamuddin (2015). Teaching English fricative sounds to the learners whose mother tongue is Hindi. Research Journal of English Language and Literature (RJELAL). Vol.3.Issue 1. Pp. 243-247.

-Nurpahmi, S. (2013). Difficulties encountered by the Buginese learners in Producing English sounds. Lentera Pendidikan, Vol. 16 No. 1. Pp. 83-90.

-O'Connor J. D. (1980). Better English pronunciation. Cambridge: Cambridge University Press.

-Osborne, D. (2008). Systematic differences in consonant sounds between the interlanguage phonology of a Brazilian learner of English and Standard American 
English. Ilha do Desterro. A Journal of English Language, Literatures in English and Cultural Studies Vo. 55, Pp. 111-132.

-Rahimpour M. \& Dovaise M. (2011). A phonological contrastive analysis of Kurdish and English. International Journal of English Linguistics Vol. 1, No. 2. Canadian Center of Science and Education. Pp. 72-82.

-Roach, P. (2009). English phonetics and phonology.

Cambridge: Cambridge University Press.
-Wester, F; Gilbers, D \& Lowie, W. (2007). Substitution of dental fricatives in English by Dutch L2 speakers. Language Sciences, 29. Pp. 477-491.

-Tuan, L. T. (2010). Teaching English Discrete Sounds through minimal pairs. Journal of Language Teaching and Research, Vol. 1, No. 5. Finland: Academy Publisher. Pp. 540-561

\section{Appendix A}

Minimal Pairs of Target Sounds Contrasted with Similar Sounds

\begin{tabular}{|c|c|c|c|c|c|}
\hline$\mapsto \diamond$ & $\leftarrow$ & $\lambda \mapsto \bigcirc$ & & $\bullet \mapsto \mapsto \bigcirc$ & $\therefore$ \\
\hline thing & sing & then & Zen & thin & thing \\
\hline thick & sick & though & zoo & $\sin$ & sing \\
\hline think & sink & breathing & breezing & sun & sung \\
\hline thin & $\sin$ & clothing & closing & win & wing \\
\hline thumb & some & teething & teezing & bun & bung \\
\hline thimble & symbol & clothe & close & pin & ping \\
\hline thank & sank & teethe & teeze & chin & ching \\
\hline things & sings & breathe & breeze & stun & stung \\
\hline mouth & mouse & bathe & bays & kin & king \\
\hline faith & face & with & whizz & ton & tongue \\
\hline tenth & tense & soothe & sues & ban & banged \\
\hline math & mass & loathe & lows & hand & hanged \\
\hline myth & miss & seethe & sees & wind & winged \\
\hline path & pass & lathe & laze & pond & ponged \\
\hline fourth & force & tithe & ties & banned & banged \\
\hline
\end{tabular}




\section{Appendix B}

Transcriptions of Subjects' Outputs of Target Sounds before and after Instruction

Student (1) Before Instruction

\begin{tabular}{|c|c|c|c|c|c|}
\hline & $\leftarrow$ & $\lambda$ & & 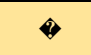 & $\therefore$ \\
\hline tink & sink & 3 & 30 & ,In & ${ }_{\leftrightarrow}$ Ink \\
\hline terk & SIk & ০:t & o: & In & IInk \\
\hline tink & sink & $\uparrow_{\rightarrow}: t i n k$ & $\uparrow_{\rightarrow}: Z I n g$ & $\leftrightarrow n$ & $\mathrm{~s} \wedge \eta \mathrm{k}$ \\
\hline t3n & s3n & $\ell$ o:tink & $\ell$ o:sink & $3 n$ & ¿In \\
\hline ta:mp & sa:mp & ↔aItInk & ${ }_{\leftrightarrow} \odot$ ISInk & $\uparrow \wedge n$ & $\uparrow \wedge n g$ \\
\hline tзmbil & sзmbil & last & lo:z & $\prec$ In & pIng \\
\hline tæ. ${ }^{\circ} \mathrm{k}$ & sæ. ${ }^{\circ} \mathrm{k}$ & $\leftrightarrow$ aIt & ↔aIs & $\mathrm{s} \wedge \mathrm{n}$ & $\mathrm{s} \wedge \eta \mathrm{k}$ \\
\hline tıng & $\mathrm{s} \wedge .{ }^{\circ} \mathrm{ks}$ & $\uparrow_{\rightarrow} \mathbf{3}_{\leftrightarrow}$ & $\uparrow_{\rightarrow} 3$ & st^n & st^引k \\
\hline mevt & mavs & $\uparrow \odot$ It & $\uparrow \odot$ IS & In & Ing \\
\hline felt & fels & ¿Iठ & IIZ & ton & ta:k \\
\hline$\leftrightarrow 3 \diamond_{\leftrightarrow}$ & $3 \bullet$ & \&aut & SUIS & bænd & bænId \\
\hline$\mp \Lambda t$ & $\mp \wedge S$ & lavt & lavs & hænd & hænId \\
\hline$\mp \odot \cap t$ & 干IS & sert & seIz & Ind & _InId \\
\hline$\prec a: t$ & $\prec \mathrm{a}: \mathrm{s}$ & Int & $\mid \odot I Z$ & $\prec$ pnd & $\prec \wedge \eta d$ \\
\hline$\succ \mathrm{s}: \mathrm{rt}$ & $\succ \mathrm{o:rt} \int$ & $\leftrightarrow$ It & $\leftrightarrow \odot$ IS & bænd & $\uparrow 3 \eta d$ \\
\hline
\end{tabular}

After Instruction

\begin{tabular}{|c|c|c|c|c|c|}
\hline & - & $\lambda$ & & 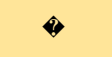 & $\therefore$ \\
\hline o.. & $\therefore \ldots$ & $\mathrm{fi}_{\swarrow} \diamond$ & $\nearrow$ & $\odot$ & $\cap \ldots$ \\
\hline o & $\therefore$ & $\mathrm{fi} \leftrightarrow$ & - & $\Omega$ & $\bigcap \ldots$ \\
\hline Šo... & $\circ \ldots$ & $\uparrow \rightarrow \nearrow$ fio & 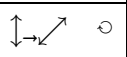 & - & - \\
\hline $\mathrm{S}_{\swarrow}$ & 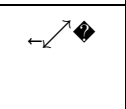 & $\begin{array}{ll}\ell \quad f i \\
0 \ldots\end{array}$ & $\begin{array}{c}\ell_{-} \\
\ldots\end{array}$ & $\Omega$ & $\Omega \ldots$ \\
\hline$\breve{S} \mp$ & $\leftarrow \mp$ & $\begin{array}{c}\odot \cap \text { @fi } \\
\ldots\end{array}$ & $\stackrel{\odot \cap \cap \cap}{\ldots}$ & $\uparrow \bullet$ & $\uparrow \quad \ldots$ \\
\hline$\breve{S}_{\swarrow} \mp \uparrow \ell \ell$ & $\begin{array}{c}\nearrow \mp \uparrow 0 \\
\ell\end{array}$ & $\ell \quad \check{S}$ & $\ell \square \leftarrow$ & $\prec \odot \cap \diamond$ & $\prec \odot \cap \ldots$ \\
\hline$\breve{S}^{\prime} \cdot \quad . \cdot$ & $+\quad \therefore$ & $\leftrightarrow \odot \cap \mathrm{fi}$ & $+\odot$ & $\leftrightarrow \rightleftharpoons \odot \circ$ & $\leftrightarrow \odot \odot \circ \ldots$ \\
\hline S̆॰...• & 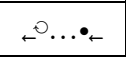 & $\uparrow \rightarrow \nearrow$ fi & $\uparrow \rightarrow \nearrow$ & $\leftrightarrow$ & $\leftrightarrow \quad \ldots$ \\
\hline$\mp \because \quad \check{S}$ & $\mp \because \quad \leftarrow$ & $\uparrow \odot \cap f i$ & $\uparrow \odot \cap$ & $\odot \cap$ & $\cap \ldots$ \\
\hline$\succ \odot \circ \breve{S}$ & $\succ \odot \odot_{\leftarrow}$ & กfi & $\Omega$ & $\triangle<$ & $\leftrightarrow<\ldots \bullet$ \\
\hline$\nearrow \triangle \check{S}$ & 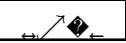 & fi & $\mapsto \cap$ & $\uparrow \diamond$ & $\ldots$ \\
\hline
\end{tabular}


Student (2) Before Instruction

\begin{tabular}{|c|c|c|c|c|c|}
\hline & $\leftarrow$ & $\lambda$ & & $\Leftrightarrow$ & $\therefore$ \\
\hline ↔nk & 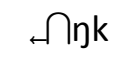 & ○n & $3 n$ & ○3n & $\Omega_{\leftrightarrow}{ }^{\circ}$ \\
\hline$\Omega$ & $\cap$ & $\leftrightarrow$ ↔t & u: & $\leftarrow \odot \cap \diamond$ & $\bigcap \cdot{ }^{\circ}$ \\
\hline$\theta$ Ink & $\Omega_{n}$ & $\uparrow$ ^i: & $\uparrow_{\text {I_i }}$ izın & ¿ & 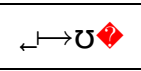 \\
\hline$\bigcirc_{3}$ & 30 & lu:tın & $\ell$ u:sin & $\Omega$ & $\bigcap . \therefore$ \\
\hline${ }_{\leftrightarrow} \wedge \mathrm{mp}$ & $\wedge \mathrm{mp}$ & il: & أن & \on & bp. $\therefore$ \\
\hline${ }_{\leftrightarrow} \mathrm{a}: \mathrm{mpıl}$ & ↔3mpıl & ləut & laUs & $\prec 3 \diamond$ & $\prec 3 .^{\circ}$ \\
\hline${ }_{\leftrightarrow} \circledast{ }^{\circ} \mathrm{k}$ & «æ. & O3t & ○3S & t $\int e ı n$ & $t \int \Lambda$ \\
\hline 丹ीks & กnks & $\uparrow_{\rightarrow} 3 \mathrm{t}$ & $\uparrow_{\rightarrow} 3 \mathrm{~S}$ & $\leftrightarrow$ æn & $\leftrightarrow$ ↔. \\
\hline$\mp \mapsto \mho t$ & $\mp \longmapsto \mho S$ & $\uparrow a: t$ & $\uparrow \odot \bigcap_{\leftarrow}$ & $\cap$ & $\cap .{ }^{*}$ \\
\hline felt & $\succ \odot \mathrm{IS}$ & $\Omega_{\leftrightarrow}$ & $\cap \cap$ & $\leftrightarrow$ ↔ & $\leftrightarrow$ ↔k \\
\hline$\leftrightarrow 3 n t$ & ↔3ns & $\leftarrow$ avt & $\leftrightarrow$ $\longmapsto z$ & $\prec æ n$ & $\prec æ n t \int$ It \\
\hline$\mp æ t$ & 干æs & $\ell \mapsto v t$ & $\ell \mapsto \mho z$ & $\hbar æ n d$ & $\hbar æ n t \int I t$ \\
\hline$\mp \odot \bigcap_{\leftrightarrow}$ & $\mp \bigcap_{-}$ & ii:d & ii:z & $\Omega \diamond$ & $\bigcap \cdot$ \\
\hline$\prec æ t$ & $\prec æ s$ & la:t & $\ell a: z$ & $\prec \longmapsto$ ond & $\prec \longmapsto$ Unt $\int$ \\
\hline$\succ \mapsto v r t$ & $\succ \mapsto v r s$ & $\bigcirc 3 t$ & $\bigcirc 3 z$ & $\prec \bigcap \diamond \bigcirc$ & $\prec \cap \diamond \mathrm{t} f$ \\
\hline
\end{tabular}

\section{After Instruction}

\begin{tabular}{|c|c|c|c|c|c|}
\hline & $\leftarrow$ & $\lambda$ & & 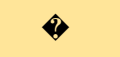 & \\
\hline$\theta_{\mathbf{I}} \cdot{ }^{\circ}$ & $\Omega . .^{\circ}$ & бзn & $3 n$ & бзn & $\theta$. \\
\hline Өeık & $\leftarrow \odot \cap$ & ${ }_{\leftrightarrow} \mathrm{U}:$ & zu: & $\cap$ & h. \\
\hline$\theta_{\text {ı. }} \cdot$ & $\Omega$. & ^_i:むı.・ & †_i:zı. & $\wedge n$ & $-\lambda$. \\
\hline ðзn & 3 & 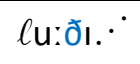 & $\ell$ u:zı. & $\bigcap$ & গ. \\
\hline$\theta \wedge \mathrm{mp}$ & $₫ \mathrm{~m}$ & ili:tı. & (i:SI. & \on & $\uparrow \phi$. \\
\hline Өзmpıl & sзmpıl & lu:t & lu:s & $\prec \bigcap$ & $\prec \emptyset$ \\
\hline$\theta æ .{ }^{\circ} \mathrm{k}$ & ææ. ${ }^{\circ} \mathrm{k}$ & ii:t & ilis & $t \int \ln$ & ts \\
\hline$\theta_{\mathbf{I}} \cdot{ }^{\circ}$ & $\bigcap \cdot \therefore$ & †_i: & $\uparrow_{\rightarrow} \mathrm{i}: \mathrm{z}$ & $\leftrightarrow n$ & $\leftrightarrow$. \\
\hline$\mp \mapsto \circlearrowright \theta$ & $\mp \longmapsto U S$ & $\uparrow æ \theta$ & $\uparrow \odot \cap$ & in & . \\
\hline$\succ \odot \cap \theta$ & $\succ \odot \bigcap_{\leftarrow}$ & $\Omega_{\leftrightarrow}$ & $\Omega$ & $\leftrightarrow n$ & A. \\
\hline$\theta$ өз $\theta$ & $\leftrightarrow 3 n s$ & «u:t & $\leftarrow U: Z$ & $\uparrow a: n d$ & \a: \\
\hline$\mp æ \theta$ & 干æs & $\ell$ u:ઇ & $\ell u: z$ & $\hbar æ n d$ & $\hbar æ$. \\
\hline$\mp \odot \bigcap \theta$ & $\mp \mathrm{i}_{\leftarrow}$ & ¿i:t & ¿i:z & $\cap \diamond 0$ & $\Omega$. \\
\hline
\end{tabular}


Student (3) Before Instruction

After Instruction

\begin{tabular}{|c|c|c|c|c|c|c|c|c|c|c|c|}
\hline & $\leftarrow$ & $\lambda$ & & $\Leftrightarrow$ & $\therefore$ & & $\leftarrow$ & $\lambda$ & & 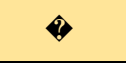 & $\therefore$ \\
\hline$\theta_{\mathbf{I}} \cdot{ }^{\circ}$ & st. ${ }^{\circ}$ & $\leftrightarrow 3 n$ & $3 n$ & In & $\theta_{\mathbf{l}} \cdot$ & $\theta_{\mathbf{1}} \cdot{ }^{\circ}$ & SI. ${ }^{\circ}$ & ðзn & $3 n$ & $\theta ı n$ & $\theta_{1 .} \cdot$ \\
\hline$\theta \mathrm{lk}$ & $\bigcap$ & ৫ & u: & $\bigcap^{\cdot}$ & $\Omega .^{\circ}$ & $\theta ı k$ & $\Omega$ & du: & u: & $\Omega$ & $\bigcap^{\circ}$ \\
\hline ก. ${ }^{\circ}$ & $\Omega$ & $\uparrow_{\rightarrow} 3 \theta_{\mathrm{I}} \cdot{ }^{\cdot}$ & $\uparrow_{\rightarrow} 3 \mathrm{zI} \cdot \cdot^{\cdot}$ & $\leftarrow$ Dn & $\Lambda$. & $\theta$ ın & $\theta_{\text {I. }} \therefore$ & bri:むı. & bri:むı. & $\wedge n$ & $\bigcap$. \\
\hline$\cap$. & $\cap$ & lu:tı. ${ }^{\cdot}$ & 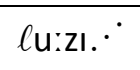 & $\Omega$ & $\Omega$. & $\theta$ ın & $\sin$ & klЈ:むı. & klo:zı. ${ }^{\bullet}$ & $\bigcap$ & $\Omega^{\circ}$ \\
\hline$\leftrightarrow \wedge \mathrm{m}$ & $₫ \mathrm{~m}$ & ii:tı. $\bullet$ & iأSI. • & $\downarrow \wedge n$ & $\lceil\wedge . \cdot$ & $\theta \wedge m$ & $\mathrm{~s} \wedge \mathrm{m}$ & teıむı. & teıðı. ${ }^{\cdot}$ & $b \wedge n$ & $b \wedge$. \\
\hline ↔3mbıl & $\leftarrow 3 \mathrm{mb}$ ।l & $\ell \mathrm{u}: \theta$ & $\ell$ u:zis & $\prec \bigcap \diamond$ & $\prec \bigcap . \therefore$ & $\theta ı m b ı l$ & sımbıl & klo:む & klo:z & $\prec \bigcap \diamond$ & $\prec \bigcap$. \\
\hline$\leftrightarrow$ ↔.”k & $\leftrightarrow æ \cdot{ }^{\circ} \mathrm{k}$ & i:S & $\leftrightarrow 35$ & $t \int ı n$ & $\mathrm{t} \int \mathrm{I}$. & $\theta æ . \cdot k$ & $\leftrightarrow \wedge \cdot{ }^{\circ} \mathrm{k}$ & taıঠ & $\mathrm{tal}_{\leftarrow}$ & $t \int ı n$ & $\mathrm{t} \int \mathrm{I}^{\circ}$ \\
\hline ก. $\therefore$ ・IS & $\cap . \therefore 15$ & $\uparrow_{\rightarrow} 3 \mathrm{~S}$ & $\uparrow_{\rightarrow}$ els & $\leftrightarrow$ & $\leftrightarrow^{3}$ & $\theta ı$. & $\bigcap \cdot \cap_{-}$ & bri: $\theta$ & bri:s & $\leftrightarrow n$ & $\leftrightarrow \wedge$. \\
\hline$\mp \longmapsto ひ \theta$ & $\mp \mapsto U \mathrm{~S}$ & $\uparrow \cap$ & $\downarrow \odot \bigcap_{\leftarrow}$ & $\cap .{ }^{\circ}$ & $\Lambda$. & $\mp \mathrm{a} v \theta$ & Favs & ba: $\theta$ & $\uparrow \odot \bigcap_{\leftarrow}$ & $\cap \bullet$ & $\cap .{ }^{\circ}$ \\
\hline$\succ \odot \cap \theta$ & $\succ \wedge S$ & $\bigcap \theta$ & $\Omega$ & $\leftrightarrow$ Dn & $\leftrightarrow_{\infty} \mathrm{Dk}$ & $\succ \odot \cap \theta$ & $\succ \odot \bigcap_{\leftarrow}$ & $\mathrm{wI} \theta$ & WIZ & $\leftrightarrow n$ & t $\wedge$. \\
\hline$\leftrightarrow 3 n s$ & $\leftrightarrow 3$ ns & $+u: \theta$ & $\llcorner\longmapsto \mho z$ & $\downarrow æ . \cdot$ & $\lceil æ . \cdot \cap \bigcirc$ & $\leftrightarrow 3 n ı \theta$ & $\leftrightarrow 3 n i s$ & su:ð & su:z & $\uparrow \wedge n$ & $\mathrm{n} \wedge . \therefore$ \\
\hline$\mp a: s$ & $\mp a: s$ & $\ell \mapsto \mho s$ & $\ell \mapsto \mho s$ & $\hbar æ n d$ & $\hbar æ$ gıd & $\mp \mathrm{a}: \theta$ & ma:s & laøঠ & lu:z & $\hbar æ n d$ & $\hbar æ . \cdot$ 听 \\
\hline$\mp \wedge \theta$ & $\mp \bigcap_{-}$ & ¿i:s & $\leftarrow$ a:s & $\cap \diamond$ & $\bigcap \cdot \therefore \cap \bigcirc$ & $\mathrm{m} ı \theta$ & $\mp \bigcap_{\leftarrow}$ & si:ઇ & iis & $\bigcap \diamond$ & 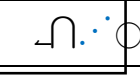 \\
\hline$\prec \mathrm{a}: \mathrm{s}$ & $\prec \mathrm{a}: \mathrm{s}$ & $\ell \mapsto \bigcap_{\leftarrow}$ & $\ell \mapsto \bigcap$ & $\prec$ pnd & $\prec \mathrm{D} .{ }^{\circ}$ id & & & & & & \\
\hline$\succ$ J:rs & $\succ$ J:ris & ilis & di:s & $\downarrow æ n ı d$ & \æ.'・ク○ & & & & & & \\
\hline
\end{tabular}


Student (4)

\begin{tabular}{|c|c|c|c|c|c|}
\hline & $\leftarrow$ & $\lambda$ & & 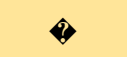 & $\therefore$ \\
\hline tı. ${ }^{\circ}$ & SI. ${ }^{\circ}$ & ○n & z3n & tın & tı. $\therefore$ \\
\hline k k & $↔ k$ & ${ }_{\leftrightarrow} \mathrm{u}:$ & $\mathrm{u}:$ & $\sin$ & sı. $\therefore$ \\
\hline tı. ${ }^{\circ}$ & sI. ${ }^{\circ}$ & $\uparrow_{\rightarrow}$ i:tı. & I_i:zI. $^{*}$ & son & so. $\therefore$ \\
\hline$\Omega^{\circ} \cdot$ & $\bigcap \diamond$ & lu:tı. & lu:zı..$^{\circ}$ & $\bigcap \bullet$ & $\bigcap \cdot \therefore$ \\
\hline${ }_{\leftrightarrow} \mathrm{Dmb}$ & sDm & i:tı. & أفي & bon & bp. $\therefore$ \\
\hline ↔3mp & $\leftrightarrow 3 m p$ & klu:t & klu:z & $\prec \bigcap \diamond$ & $\prec \bigcap . \therefore$ \\
\hline tı. ${ }^{\circ}$ & sI. ${ }^{\circ}$ & ti:t & ti:z & $t \int \cap$ & $t \int \cap . \therefore$ \\
\hline tı. ${ }^{\cdot}$ & $\mathrm{SI} \cdot{ }^{\cdot} \leftarrow$ & bri:t & $\uparrow \rightarrow \cap$ & stpn & sto. $\therefore$ \\
\hline mavt & mavs & bri:む & \DIz & $\cap$ & $\cap . \therefore$ \\
\hline$\succ \mathrm{It}$ & $\succ \odot \bigcap_{\leftarrow}$ & $\Omega_{\leftrightarrow}$ & $\bigcap$ & ton & to. $\therefore$ \\
\hline t3nt & t3ns & $\wedge \mathrm{m}$ & su:z & bo:nd & bว:. ${ }^{\circ} \bigcirc$ \\
\hline$\mp \bigcap_{\leftrightarrow}$ & $\mp \odot \bigcap_{\leftarrow}$ & lavt & lavz & ћænd & hændı. $\therefore$ \\
\hline$\mp \bigcap_{\leftrightarrow}$ & $\mp \bigcap_{\leftarrow}$ & æt & sæz & $\bigcap \diamond 0$ & $\bigcap \diamond \bigcirc . \therefore$ \\
\hline pæt & pæs & l3t & 132 & pond & poind $\bigcap \bigcirc$ \\
\hline$\succ_{\rightarrow} \mathrm{avt}$ & $\succ_{\rightarrow} \odot \bigcap_{r}$ & ili:t & ti:z & ¡ænd & \a:rın \\
\hline
\end{tabular}

After Instruction

\begin{tabular}{|c|c|c|c|c|c|}
\hline & $\leftarrow$ & $\lambda$ & & $\Leftrightarrow$ & $\therefore$ \\
\hline$\theta_{\text {I. }} \cdot$ & SI..$^{\circ}$ & бзn & $z 3 n$ & $\theta ı n$ & $\theta_{\mathrm{I}} \cdot$ \\
\hline$\theta ı k$ & $\bigcap$ & u: & zu: & $\bigcap$ & $\bigcap \cdot{ }^{\circ}$ \\
\hline$\theta_{\text {I. }} \cdot$ & SI. ${ }^{\circ}$ & १_i:むı. & $\uparrow_{\rightarrow} \mathrm{i}: z \mathrm{zI} \cdot{ }^{\cdot}$ & sDn & sD..$^{\circ}$ \\
\hline$\theta \cap$ & $\bigcap$ & klu:むı.• & klu:zı. & $\bigcap$ & $\bigcap \cdot{ }^{\circ}$ \\
\hline$\theta 3 m$ & $3 m$ & ti:むı. & ti:zı..$^{\circ}$ & bon & bo. \\
\hline Өзmbıl & s3mbıl & klu:ઇ & klu:z & $\prec \bigcap \diamond$ & $\prec \bigcap$. \\
\hline$\theta a_{: .} \cdot$ & sa:. & ti:ठ & ti:z & $t \int \ln$ & $\mathrm{t} \int \mathrm{I}^{\circ}$ \\
\hline$\theta \mathbf{l} .{ }^{\circ}$ & SI. $\therefore$ & bri:む & bri:z & ston & sto. \\
\hline $\operatorname{mav} \theta$ & maus & bıঠ & b3z & $\cap$ & $\cap .{ }^{\circ}$ \\
\hline$f i \theta$ & fIS & WIઇ & $\Omega$ & ton & to. \\
\hline $\tan \theta$ & t3ns & su:ઇ & su:z & b^nd & bı. ${ }^{\circ}$ \\
\hline ma: $\theta$ & $\mp \bigcap_{\leftarrow}$ & lu:ð & lu:z & hænd & $\hbar æ$. \\
\hline meı $\theta$ & $\mp \odot \bigcap_{k}$ & si:ð & si:z & $\Omega \gg 0$ & $\Omega \cdot^{\circ}$ \\
\hline
\end{tabular}


Student (5) Before Instruction

\begin{tabular}{|c|c|c|c|c|c|}
\hline & $\leftarrow$ & $\lambda$ & & $\Delta$ & $\therefore$ \\
\hline ก. & ก. & ðзn & $\mathrm{z3n}$ & $\Omega$ & $\bigcap . \cap^{\prime}$ \\
\hline$\theta \mathrm{lk}$ & sık & כ: & ZJ: & $\Omega$ & $\wedge . \therefore$ \\
\hline$\theta \mathrm{k}$ & $\Omega \cdot$ & $\uparrow_{\rightarrow}$ Зठ। & $\uparrow_{\rightarrow}, 3 \mathrm{ZI}$ & ¿Dn & $\leftarrow \mathrm{D} . \therefore$ \\
\hline$\theta ı n$ & $\sin$ & $\ell$ ८:む। & $\ell כ: z 1$ & $\Omega$ & $\Omega$. \\
\hline$\theta \mathrm{pm}$ & ${ }_{\leftarrow}^{\mathrm{Dm}}$ & أف:SI. & $\begin{array}{c}\leftrightarrow \odot \cap \\
\cap .\end{array}$ & bpn & bo. $\therefore$ \\
\hline $\begin{array}{c}\bigcap \mp \uparrow \cap \\
\ell\end{array}$ & $\begin{aligned} \leftarrow & \odot \cap \mp \\
& \uparrow \cap \ell\end{aligned}$ & $\ell כ: s$ & lo:s & $\prec \cap$ & $\prec \bigcap . \therefore$ \\
\hline æ. & ¿a:. & i:s & $\leftrightarrow \odot \bigcap_{-}$ & $t \int \cap$ & $\mathrm{t} \int \mathrm{a} \cdot$ \\
\hline $\begin{array}{c}\theta \cap \\
\bullet \bigcap_{\leftarrow}\end{array}$ & $\begin{array}{c}\bigcap_{\bullet} \cdot \\
\bullet \bigcap_{\leftarrow}\end{array}$ & $\uparrow_{\rightarrow} 3 \mathrm{~S}$ & $\uparrow_{\rightarrow}$ ii:s & $\leftrightarrow_{\mathrm{Dn}}$ & $\leftrightarrow \mathrm{D} . \therefore$ \\
\hline 干aus & 干aus & $\uparrow æ s$ & $\uparrow \odot \bigcap_{\leftarrow}$ & $\cap \bullet$ & ก. $\therefore$ \\
\hline faı $\theta$ & fsal & Øঠ & $\Omega$ & tno & to. $\therefore$ \\
\hline$\leftrightarrow 3 n \theta$ & $\leftrightarrow 3 n s$ & ¿u:s & ๔UIZ & \a:nd & $\uparrow a_{:}: \circ \bigcirc$ \\
\hline$\mp a: s$ & $\mp a: s$ & loIs & lavz & $\hbar æ n d$ & hæ. $\cdot \bullet$ \\
\hline$\mp \odot \bigcap_{\leftarrow}$ & $\mp \odot \bigcap_{\leftarrow}$ & ¿i:s & $\leftarrow \odot \cap$ & $\_a ı$ & $\bigcap \cdot \bullet \bigcirc$ \\
\hline$\prec a: s$ & $\prec a: s$ & lass & la:s & pond & 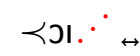 \\
\hline$\succ \rho: r ı \theta$ & $\succ$ J:rIs & ↔i:むə & i:z & ¡a:nd & $\uparrow a_{:} \cdot{ }_{\leftrightarrow}$ \\
\hline
\end{tabular}

After Instruction

\begin{tabular}{|c|c|c|c|c|c|}
\hline & $\leftarrow$ & $\lambda$ & & 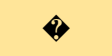 & $\therefore$ \\
\hline$\theta_{\text {ı. }} \cdot$ & ↔..$^{\circ}$ & бзn & $z 3 n$ & $\theta$ ın & $\theta_{1} \cdot$ \\
\hline$\theta ı k$ & sık & дu: & zu: & $\Omega$ & $\leftarrow .^{\circ}$ \\
\hline$\theta_{1 .} \cdot$ & SI..$^{\circ}$ & brзむı. & $\uparrow_{\rightarrow} i_{i z I} \cdot$ & $s \wedge n$ & sı..$^{\circ}$ \\
\hline$\theta ı n$ & $\sin$ & klэ:むı. & klo:zı. & $\Omega$ & _.. \\
\hline ঠیm & $₫ \mathrm{~m}$ & ti:むı. & ti:zı. ${ }^{\circ}$ & \on & bo. \\
\hline$\theta$ өзmbıl & s3mbıl & klo:ઇ & klo:z & $\prec \bigcap \diamond$ & $\prec \bigcap \cdot{ }^{\circ}$ \\
\hline$\theta æ . \cdot$ & æ.' & ti:ઇ & tzi: & $t \int 1 \otimes$ & $\mathrm{t} \int \mathrm{I}^{\circ}$ \\
\hline$\theta_{\mathbf{l}} \cdot{ }^{\circ}$ & SI. $\therefore$ & bri:ð & bri:z & $\leftrightarrow \mathrm{pn}$ & stb. \\
\hline $\operatorname{mav} \theta$ & mars & beıঠ & beız & $\cap$ & $\cap . .^{\circ}$ \\
\hline faı $\theta$ & fais & WIঠ & $\Omega$ & ton & to. \\
\hline $\tan \theta$ & t3ns & su:ઇ & su:z & ba:nd & ba:. ${ }^{\circ} \bigcirc$ \\
\hline $\mathrm{ma}: \theta$ & 干a:s & lu:ð & lu:z & hænd & hæ.' $\bigcirc$ \\
\hline$m a ı$ & $I \cap$ & si:ð & si:z & $\cap \diamond$ & $\cap \cdot \cap$ \\
\hline
\end{tabular}


Student (6)

\begin{tabular}{|c|c|c|c|c|c|}
\hline & $\leftarrow$ & $\lambda$ & & 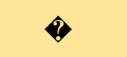 & $\therefore$ \\
\hline$\theta_{1} \cdot{ }^{\circ}$ & SI. ${ }^{\circ}$ & ðзn & $3 n$ & ðзn & $\theta_{1}$. \\
\hline$\theta \mathrm{lk}$ & sık & זəठ & əठ & $\Omega$ & $\cap$. \\
\hline$\theta_{1 .} \cdot$ & SI. ${ }^{\circ}$ & $\uparrow_{\rightarrow} \mathrm{i}: \theta_{\mathrm{I}} \cdot \cdot$ & $\uparrow_{\rightarrow}$ i:zI. & $\leftrightarrow n$ & $\mathrm{~s} \wedge . \therefore$ \\
\hline d3n & $\bigcap \diamond$ & ८ว:むı. & lJ:ZI. & aıın & $\bigcap \therefore$ \\
\hline $\mathrm{t} \wedge \mathrm{m}$ & $\mathrm{s} \wedge \mathrm{m}$ & i:SI. & ↔i:SI. & $\uparrow \wedge n$ & bp. $\therefore$ \\
\hline ↔3mpıl & $\leftrightarrow 3 \mathrm{mpıl}$ & $\ell$ u:s & $\ell$ u:s & $\prec \bigcap \diamond$ & $\prec \bigcap . \therefore$ \\
\hline$\theta æ .{ }^{\cdot}$ & sæ. ${ }^{\circ}$ & ili:s & ilis & $t \int \cap$ & $\mathrm{t} \int \cap . \therefore$ \\
\hline$\theta_{\text {I. }} \cdot$ & sı. ${ }^{\circ}$ & $\uparrow_{\rightarrow}$ i:s & $\uparrow_{\rightarrow} i: z$ & $\leftrightarrow \wedge n$ & $\leftrightarrow \cap . \therefore$ \\
\hline 干avs & Favs & $\uparrow æ z$ & $\uparrow \odot \cap$ & $\bigcap$ & $\bigcap \cdot \therefore$ \\
\hline$\succ \odot \bigcap_{\leftarrow}$ & $\succ \odot \bigcap_{\leftarrow}$ & $\Omega$ & 凤० & (סn & ${ }_{\leftrightarrow} \wedge . \therefore$ \\
\hline бзns & ↔3ns & $\leftarrow$ avs & ¿u:s & \ænd & $\uparrow v \cdot{ }^{\circ} \bigcirc$ \\
\hline$\mp a: s$ & 干æs & $\ell \wedge S$ & lavs & $\hbar æ n d$ & $\hbar æ . \cdot \bullet$ \\
\hline$\mp \mathrm{a} ı \theta$ & $\mp \bigcap_{\leftarrow}$ & ¿i:s & $\leftarrow \odot \cap$ & _aın & $\cap 0$ \\
\hline$\prec æ s$ & $\prec æ s ı S$ & $\ell æ_{\leftarrow}$ & $\ell \wedge z$ & $\prec \mathrm{D} \diamond$ & $\prec$ p. ${ }^{\circ} \bigcirc$ \\
\hline$\succ$ J:rs & $\succ \mathrm{J}$ :rs & „ilis & ilis & $\prec æ n d$ & pæ. ${ }^{\circ} \bigcirc$ \\
\hline
\end{tabular}

After Instruction

\begin{tabular}{|c|c|c|c|c|c|}
\hline & $\leftarrow$ & $\lambda$ & & $\Delta$ & $\therefore$ \\
\hline$\theta_{1 .} \cdot$ & њ. & ðзn & $z 3 n$ & $\theta ı n$ & $\theta_{1} \cdot$ \\
\hline$\theta ı k$ & sik & むu: & $z u:$ & $\sin$ & sl. ${ }^{\circ}$ \\
\hline$\theta_{\mathbf{l}} \cdot{ }^{\circ}$ & SI. ${ }^{\circ}$ & bri:むı. & bri:zı. ${ }^{\circ}$ & $s \wedge n$ & sı..$^{\circ}$ \\
\hline$\theta$ ın & $\sin$ & klu:むı.• & klu:zı. & $\Omega$ & WI. ${ }^{\circ}$ \\
\hline$\theta \wedge m$ & $₫ \mathrm{~m}$ & ti:むı. & ti:zı. & $\lceil\wedge n$ & $b_{n}$. \\
\hline$\theta ı m b ı l$ & s3mbıl & kləひઇ & kləひz & $\prec \bigcap \diamond$ & pı. \\
\hline$\theta æ \cdot \cdot$ & sæ.' & t3nð & t3nz & $t \int \cap \bullet$ & t $\int_{1 .}{ }^{\circ}$ \\
\hline$\theta_{\mathbf{l}} \cdot{ }_{\bullet}$ & SI. $\therefore$ & bræঠ & bræz & st^n & stı. \\
\hline $\operatorname{mav} \theta$ & mars & $\uparrow \odot \bigcap ઇ$ & $\uparrow \odot \cap$ & $\cap$ & kı. ${ }^{\circ}$ \\
\hline feı $\theta$ & $\succ \odot \bigcap_{\leftarrow}$ & ภঠ & $\Omega$ & $\mathrm{t} \wedge \mathrm{n}$ & $\mathrm{t} \wedge$. \\
\hline $\operatorname{t3n} \theta$ & t3ns & su:ঠ & su:z & bænd & bæ. ${ }^{\circ} \bigcirc$ \\
\hline $\mathrm{m} æ \theta$ & mæs & lu:ð & lu:z & hænd & hæ. ${ }^{\circ} \bigcirc$ \\
\hline $\mathrm{mIA}$ & mis & క३đ & 537 & $\cap \Delta \wedge$ & $\ldots \cdot \frown$ \\
\hline
\end{tabular}


Student (7) Before Instruction

\begin{tabular}{|c|c|c|c|c|c|}
\hline & $\leftarrow$ & $\lambda$ & & 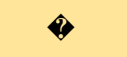 & $\therefore$ \\
\hline$\theta_{\mathbf{I}}$. & SI. & бзn & $z 3 n$ & бзп & $\theta_{\mathrm{I}} \cdot{ }^{\circ}$ \\
\hline$\leftrightarrow \odot \bigcap$ & $\leftarrow \odot \cap$ & tu: & zu: & s3n & sl. ${ }^{\circ}$ \\
\hline tı. ${ }^{\circ}$ & sI. ${ }^{\circ}$ & bri:む.• & bri:zı. & $s \wedge n$ & sı. $\therefore$ \\
\hline ○n & s3n & klu:むı. $\cdot$ & klu:sı. ${ }^{\circ}$ & $\bigcap$ & $\bigcap . \therefore$ \\
\hline tomp & sDm & ti: $\theta_{\imath} \cdot$ & t3si..$^{\circ}$ & bpn & bav. $\therefore$ \\
\hline t3mbıl & s3mbıl & kbl $\theta$ & klu:s & $\prec \bigcap \diamond$ & $\prec \bigcap . \therefore$ \\
\hline tæ..$^{\cdot}$ & sa:. & teı $\theta$ & ${ }_{\leftrightarrow} \odot \bigcap_{\leftarrow}$ & $t \int ı n$ & $\mathrm{t} \int \mathrm{I} \cdot \therefore$ \\
\hline$\theta_{\mathbf{I}} \cdot \bullet$ & SI. $\cdot$ & bri: $\theta$ & bri:z & stın & stı. $\therefore$ \\
\hline $\operatorname{mav} \theta$ & maus & 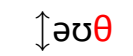 & $\uparrow \odot \bigcap_{\leftarrow}$ & $\cap$ & ก. ${ }^{\cdot} \leftrightarrow$ \\
\hline$\succ \odot \cap \theta$ & $\succ \odot \bigcap_{\leftarrow}$ & Øঠ & $\left\llcorner\odot \bigcap_{\leftarrow}\right.$ & tarn & tav.. \\
\hline $\tan \theta$ & t3ns & 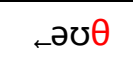 & $\leftarrow \partial \mho z$ & ba:nd & bav $\theta$ \\
\hline ma:t & ma:s & $\operatorname{lav} \theta$ & lavs & ha:nd & $\hbar \odot \bigcap_{\leftrightarrow}$ \\
\hline $\mathrm{ma}: \theta$ & $\mp \bigcap_{\leftarrow}$ & s3 $\theta$ & $\leftarrow \odot \bigcap_{\leftarrow}$ & $\bigcap \diamond$ & $\left\llcorner\odot \bigcap_{\leftrightarrow}\right.$ \\
\hline pa:t & pa:s & $\operatorname{lav} \theta$ & la:s & parnd & pav. $\cdot d$ \\
\hline fo:r $\theta$ & fo:rs & ${ }_{\leftrightarrow} \odot \cap \theta$ & ti:s & pænıt & $\prec \Lambda .{ }^{\prime} \leftrightarrow_{\leftrightarrow}$ \\
\hline
\end{tabular}

After Instruction

\begin{tabular}{|c|c|c|c|c|c|}
\hline & $\leftarrow$ & $\lambda$ & & $\Leftrightarrow$ & $\therefore$ \\
\hline$\theta_{\text {I.. }} \cdot$ & SI. ${ }^{\circ}$ & ઇ3n & $z 3 n$ & dın & $\theta_{\mathrm{I}}$. \\
\hline$\theta \mathrm{lk}$ & sık & ठu: & zu: & $\Omega$ & SI..$^{\circ}$ \\
\hline$\theta_{\mathbf{I} .} \cdot$ & sI. ${ }^{\circ}$ & $\begin{array}{c}\text { bri:むı } \\
.\end{array}$ & bri:zı. & $s \wedge n$ & SA. \\
\hline$\theta 3 n$ & s3n & $\begin{array}{c}\text { klu:むı } \\
.\end{array}$ & $\begin{array}{c}\text { klu:zı } \\
.\end{array}$ & $\Omega$ & WI. ${ }^{\circ}$ \\
\hline$\theta \wedge m$ & $\mathrm{~s} \wedge \mathrm{m}$ & ti:むı. & $\begin{array}{c}\leftrightarrow \odot \bigcap_{A} 1 \\
\therefore\end{array}$ & bon & bp. \\
\hline Өзmbıl & s3mbıl & klu:ठ & klu:z & $\prec \bigcap \diamond$ & pI. \\
\hline Өæ. ${ }^{\cdot}$ & sæ. ${ }^{\bullet}$ & teıठ & ${ }_{\leftrightarrow} \odot \bigcap_{\leftarrow}$ & $t \int ı n$ & $\mathrm{t} \int \mathrm{I}^{\circ}$ \\
\hline$\theta_{1 .} \cdot \leftarrow$ & SI. ${ }^{\circ}$ & $\downarrow \odot \bigcap ঠ$ & $\uparrow_{\rightarrow} \odot \cap$ & st^n & stı..$^{\circ}$ \\
\hline
\end{tabular}


Student (8) Before Instruction

\begin{tabular}{|c|c|c|c|c|c|}
\hline & $\leftarrow$ & $\lambda$ & & 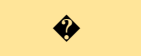 & $\therefore$ \\
\hline tı. & SI..$^{\circ}$ & d3n & $z 3 n$ & $\leftrightarrow \bullet$ & $\bigcap^{\circ} .^{\circ}$ \\
\hline tık & sık & $\theta a v$ & $z u:$ & $\Omega$ & $\cap$. \\
\hline tı. ${ }^{\circ}$ & sI. ${ }^{\circ}$ & bri:tı. & bri:zı. ${ }^{\circ}$ & $s \wedge n$ & $\leftrightarrow \wedge .^{\circ}$ \\
\hline$\leftrightarrow$ & $\bigcap$ & klu:tı. & klu:sı.• & $\bigcap$ & $\bigcap \cdot{ }^{\circ}$ \\
\hline$\theta \wedge \mathrm{mp}$ & $\mathrm{s} \wedge \mathrm{m}$ & ti:tı. & ti:sı. $^{\cdot}$ & $b \wedge n$ & bn.. \\
\hline s3mpıl & s3mpıl & klu:ts & klos & $\prec \bigcap \diamond$ & $\prec \bigcap .^{\circ}$ \\
\hline tæ. $\cdot$ & sæ.' & ti:t & ti:s & $t \int ı n$ & $\mathrm{t} \int \mathrm{I}^{\circ}$ \\
\hline$\theta_{1} \cdot{ }^{\circ}$ & ¿..$^{\circ}$ & $\uparrow_{\rightarrow} \odot \bigcap_{\leftrightarrow}$ & $\uparrow_{\rightarrow} \odot \bigcap_{\leftarrow}$ & ston & $\leftrightarrow$ ↔. \\
\hline mavt & mars & bit & $\uparrow \odot \bigcap_{\leftarrow}$ & $\cap \vartheta$ & $\cap . .^{\circ}$ \\
\hline$\succ \odot \bigcap_{\leftrightarrow}$ & fa:s & $\Omega_{\leftrightarrow}$ & $\Omega$ & ton & t八. \\
\hline ti.t & t3ns & sot & $\longleftarrow \mho Z Z$ & bænd & bæ. ${ }^{\circ} \bullet_{\leftrightarrow}$ \\
\hline mæt & mæs & læt & lavs & hænd & hæ. ${ }^{\prime}$ \\
\hline$\mp \odot \bigcap_{\leftrightarrow}$ & $\mp \odot \bigcap_{\leftarrow}$ & $\Omega$ & ii:s & $\prec \bigcap \diamond \bigcirc$ & $\prec \bigcap . \bullet_{\leftrightarrow}$ \\
\hline pa:t & pa:s & l3t & la:s & pond & ppv. ${ }^{\circ} \cap \bigcirc$ \\
\hline fo:rt & fo:rs & On & ti:s & \ænd & bæ.'・ク○ \\
\hline
\end{tabular}

112
After Instruction

\begin{tabular}{|c|c|c|c|c|c|}
\hline & $\leftarrow$ & $\lambda$ & & $\Leftrightarrow$ & $\therefore$ \\
\hline$\theta_{1 .} \cdot$ & sI. ${ }^{\circ}$ & ðзn & z3n & $\theta$ ın & $\theta_{\text {l. }} \cdot$ \\
\hline$\theta$ & $\Omega$ & ðu: & zu: & $\Omega$ & $\Omega .^{\circ}$ \\
\hline өæ.' & s3. & $\begin{array}{c}\text { bri:むı } \\
\text {. }\end{array}$ & bri:zı. & sın & sı. \\
\hline$\theta$ ın & $\bigcap$ & $\begin{array}{c}\text { klu:む। } \\
\therefore\end{array}$ & $\begin{array}{c}\text { klu:zı } \\
\therefore\end{array}$ & WIn & wI. ${ }^{\circ}$ \\
\hline$\theta \wedge \mathrm{m}$ & $\mathrm{s} \wedge \mathrm{m}$ & ti:むı. & أف:SI. & $b \wedge n$ & $\mathrm{bn}$. \\
\hline Өæmbıl & sæmbıl & klu:ð & klu:z & $\prec \bigcap \diamond$ & $\prec \bigcap$. \\
\hline$\theta æ . \cdot$ & sæ.' & ti:ð & ti:z & $t \int ı n$ & $\mathrm{t} \int \mathrm{I} \cdot$ \\
\hline$\theta_{\mathbf{l}} \cdot \therefore$ & $\bigcap . \therefore$ & bri:ð & bri:z & st^n & stı..$^{\circ}$ \\
\hline $\operatorname{mav} \theta$ & maus & beı $\theta$ & beız & 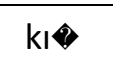 & kı. \\
\hline
\end{tabular}


Student (9)

\begin{tabular}{|c|c|}
\hline & $\leftarrow$ \\
\hline$\theta_{\text {I.. }} \cdot$ & SI. ${ }^{\circ}$ \\
\hline$\theta$ Ik & sık \\
\hline$\theta_{\text {І. }} \cdot$ & SI..$^{\circ}$ \\
\hline dın & $\sin$ \\
\hline$\theta a_{:} \cdot$ & $\mathrm{sa}_{\mathrm{a}} \cdot{ }^{\cdot}$ \\
\hline Өзmbl & seımbl \\
\hline$\theta æ . \cdot$ & sæ. ${ }^{\cdot}$ \\
\hline$\theta_{\mathbf{l}} \cdot \therefore$ & SI. ${ }^{\bullet} \bullet$ \\
\hline $\operatorname{mav} \theta$ & mavs \\
\hline$\succ \odot \bigcap_{\leftarrow}$ & $\succ 35$ \\
\hline t3ns & t3ns \\
\hline mæs & mæs \\
\hline$\mp \odot \bigcap_{\leftarrow}$ & $\mp \bigcap_{\leftarrow}$ \\
\hline
\end{tabular}

Before Instruction

\begin{tabular}{|c|c|c|c|}
\hline$\lambda$ & & $\theta$ & $\therefore$ \\
\hline ðзn & $\mathrm{z} 3 \mathrm{n}$ & $\theta ı n$ & $\theta_{1 .} \cdot$ \\
\hline$\theta u:$ & zu: & $\sin$ & SI. ${ }^{\circ}$ \\
\hline$\uparrow_{\rightarrow} 3 む_{\iota .} \cdot$ & $\uparrow_{\rightarrow} 3 \mathrm{ZI} . .^{\cdot}$ & $s \wedge n$ & sı..$^{\circ}$ \\
\hline klausı. & klauzı. & WIn & WI. \\
\hline ti:むı. & ti:sı. ${ }^{\circ}$ & $b \wedge n$ & $\mathrm{~b} \wedge$. \\
\hline klaus & klaus & pın & pl. ${ }^{\circ}$ \\
\hline ti:s & t3s & $t \int \operatorname{In}$ & $\mathrm{t} \int \mathrm{I}$. \\
\hline br3z & $\uparrow \rightarrow \odot \cap$ & stpn & stb. \\
\hline ba:s & $\uparrow \odot \bigcap_{\leftarrow}$ & kın & kı. \\
\hline クঠ & wi:s & ton & to. \\
\hline su:z & sauz & bænd & bæ. $\cdot \bullet \bigcirc$ \\
\hline li:s & lu:s & hænd & hæ. $\therefore \cap \bigcirc$ \\
\hline si: $\theta$ & $\leftarrow \odot \cap$ & win & WI. $\cdot{ }_{\leftrightarrow}$ \\
\hline
\end{tabular}

\begin{tabular}{|c|c|c|c|c|c|}
\hline & $\leftarrow$ & $\lambda$ & & $\Leftrightarrow$ & $\therefore$ \\
\hline$\theta_{\text {I. }} \cdot$ & ↔. & ð3n & $23 n$ & $\theta ı n$ & $\theta_{1}$. \\
\hline$\theta ı k$ & sık & du: & $z u:$ & $\Omega$ & sı. \\
\hline$\theta_{\text {I. }} \cdot$ & ↔.. & bri: $\theta ı$. & bri:zı. & $s \wedge n$ & SA. \\
\hline$\theta ı n$ & $\sin$ & klaひむı. & klazzı. & $\Omega$ & $\Omega$ \\
\hline$\theta \wedge \mathrm{m}$ & $\mathrm{s} \wedge \mathrm{m}$ & ti:むı.• & ti:sı. ${ }^{\cdot}$ & $b \wedge n$ & $b_{\wedge} . .^{\circ}$ \\
\hline Өзmbl & s3mbl & klaひঠ & klaus & pın & pı. \\
\hline Өæ.' & sæ.'• & ti:ð & ti:s & $t \int \operatorname{In}$ & $\mathrm{t} \int \mathrm{I}$. \\
\hline$\theta_{\mathbf{l}} \cdot{ }^{\circ}$ & ↔.. & pri:ð & pri:z & st^n & stı..$^{\circ}$ \\
\hline $\operatorname{mav} \theta$ & mavs & p3z & p3s & kın & $\mathrm{kl}^{\circ}$ \\
\hline faı $\theta$ & $f_{35}$ & WIS & WIZ & ton & to. \\
\hline $\operatorname{ti} n A$ & tanc & エוI & 8117 & hand & hm: \\
\hline
\end{tabular}

After Instruction 


\begin{tabular}{||c|c||c|c||c|c||}
\hline mæ $\theta$ & mæs & lз $\theta$ & lзz & pond & po. $\cdot \leftrightarrow_{\leftrightarrow}$ \\
\hline fว:rs & fว:rs & ti: $\theta$ & t3z & pænk & pæ. $\cdot{ }_{\leftrightarrow}$ \\
\hline
\end{tabular}

Student (10)

\begin{tabular}{|c|c|c|c|c|c|}
\hline & $\leftarrow$ & $\lambda$ & & 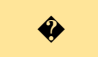 & $\therefore$ \\
\hline tı. ${ }^{\circ}$ & sı. ${ }^{\circ}$ & t3n & s3n & t3n & tı. \\
\hline taık & saık & tav & səus & $s \mid$ & SI. ${ }^{\circ}$ \\
\hline tı. ${ }^{\circ}$ & sı..$^{\circ}$ & bri:tı. & bri:zı. & spn & SD. \\
\hline tın & $\sin$ & klavtı. & klausı. & $w 1 \bullet$ & WI. \\
\hline $\mathrm{t} \wedge \mathrm{m}$ & $₫ \mathrm{Dm}$ & teıtı. ${ }^{\circ}$ & teısı. ${ }^{\circ}$ & baon & baz. \\
\hline tзmpl & ssmpl & klavt & klaus & pзn & p3. \\
\hline tæ..$^{\circ}$ & sæ.• & teit & teis & $t \int 3 n$ & $\mathrm{t} \int 3 .^{\circ}$ \\
\hline tı. $\therefore$ & SI. $\therefore$ & brelt & breis & st^n & stı. \\
\hline mavt & mars & beit & beisıs & $\mathrm{k} 1 \bullet$ & kı. \\
\hline fait & fa:s & weIt & beisıs & ton & to. \\
\hline
\end{tabular}

114

Before Instruction

\begin{tabular}{|c|c|c|c|c|c|}
\hline & $\leftarrow$ & $\lambda$ & & $\theta$ & $\therefore^{\circ}$ \\
\hline$\theta_{\text {I. }} \cdot$ & ஃ. & бзn & $z 3 n$ & $\theta_{1} \otimes$ & $\theta_{\text {I. }} \cdot$ \\
\hline Өænk & sænk & du: & zu: & $\mathrm{sl} \otimes$ & Sl. ${ }^{*}$ \\
\hline$\theta_{\mathbf{l}} \cdot{ }^{\circ}$ & Ł.. & $\begin{array}{c}\text { brbđı } \\
\therefore\end{array}$ & $\begin{array}{c}\text { brauzl } \\
.\end{array}$ & sın & sı..$^{\circ}$ \\
\hline$\theta$ өз & s3n & $\begin{array}{c}\text { klu:むı } \\
\therefore\end{array}$ & klu:zı..$^{\circ}$ & $\Omega$ & $\Lambda .^{\circ}$ \\
\hline$\theta \mathrm{pm}$ & sDm & tæӨı. & tæzı. $\therefore$ & baun & bav. \\
\hline Өзmbl & s3mbl & kləひt & klaus & рзп & pı. ${ }^{\circ}$ \\
\hline$\theta_{\mathbf{I}} \cdot{ }^{\circ}$ & њ..$^{\circ}$ & teı $\theta$ & teis & $t \int \operatorname{In}$ & $\mathrm{t} \int \mathrm{I}^{\circ}$ \\
\hline Өænks & sænks & braı $\theta$ & braıs & st $\wedge n$ & st $\Lambda$. \\
\hline $\operatorname{mav} \theta$ & mavs & bæ $\theta$ & bæz & $k_{1} \otimes$ & $\mathrm{kl}^{\circ}$ \\
\hline
\end{tabular}




\begin{tabular}{|c|c|c|c|c|c|}
\hline t3nt & t3ns & savt & savz & bænd & bæ. $\cdot \bullet d$ \\
\hline mæt & $\mp \odot \bigcap_{\leftarrow}$ & laıt & lavs & hænd & hæ. $\cdot{ }^{\prime}$ Id \\
\hline melt & meisıs & selt & sels & wind & welt \\
\hline pæt & pæsıs & leıt & leıs & pænd & pæ. •ıd \\
\hline farrt & faurs & tait & tais & $\uparrow_{\rightarrow}$ aıən & bræ.' \\
\hline
\end{tabular}




\section{Appendix C}

\begin{tabular}{|c|c|c|c|c|c|c|c|c|c|c|c|c|c|c|c|c|c|c|c|}
\hline \multicolumn{20}{|c|}{ Test Results before Instruction } \\
\hline \multirow{2}{*}{ Subjects } & \multicolumn{4}{|c|}{ libstitutes } & \multicolumn{6}{|c|}{ tubstitutes } & \multicolumn{6}{|c|}{ ubstitutes } & \multicolumn{3}{|c|}{ Errors } \\
\hline & $/ \mathrm{t} /$ & /s/ & /d/ & $\infty$ & $/ \mathrm{t} /$ & /s/ & 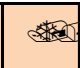 & /d/ & $|z|$ & $/ \mathrm{m} /$ & $2 y_{0}$ & red & Sacen & pens: & 12 & 尼 & 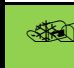 & a deap & e \\
\hline S1 & 15 & & & & 13 & & & 1 & & & 3 & 5 & 3 & & & & 15 & 14 & 11 \\
\hline S2 & 13 & & 1 & & 11 & & 2 & 2 & & & 2 & 4 & 1 & 4 & & & 14 & 15 & 11 \\
\hline S3 & 6 & 4 & & & 4 & 7 & 4 & & & & 7 & 3 & & & & & 10 & 15 & 10 \\
\hline S4 & 15 & & & & 12 & & & 1 & & 1 & 10 & & 4 & & & & 15 & 14 & 14 \\
\hline S5 & & 7 & & & & 10 & & & & & 14 & 1 & & & & & 7 & 10 & 15 \\
\hline S6 & 2 & 6 & & 1 & & 10 & 1 & & 2 & & 10 & 1 & 1 & & & & 9 & 13 & 12 \\
\hline S7 & 7 & & 1 & & 1 & & 10 & & & & 7 & 2 & & & 1 & 8 & 8 & 11 & 18 \\
\hline S8 & 12 & 1 & & & 12 & 1 & 1 & 1 & & & 5 & 8 & & & & & 13 & 15 & 13 \\
\hline S9 & & 5 & & 1 & & 5 & 4 & & 2 & & 5 & 10 & & & & & 6 & 11 & 15 \\
\hline S10 & 15 & & & & 15 & & & & & & 3 & 11 & & & & & 15 & 15 & 14 \\
\hline \multirow[t]{3}{*}{ Totals } & 85 & 23 & 2 & 2 & 68 & 33 & 22 & 5 & 4 & 1 & 66 & 45 & 9 & 4 & 1 & 8 & 112 & 133 & 133 \\
\hline & $75 \%$ & $21 \%$ & $2 \%$ & $2 \%$ & $50 \%$ & $25 \%$ & $17 \%$ & $4 \%$ & $3 \%$ & $1 \%$ & $49 \%$ & $34 \%$ & $7 \%$ & $3 \%$ & $1 \%$ & $6 \%$ & $75 \%$ & $89 \%$ & $89 \%$ \\
\hline & & & & & & & & & & & & & & & & & \multicolumn{2}{|c|}{ Total Errors } & $\begin{array}{l}378 \\
84 \%\end{array}$ \\
\hline
\end{tabular}




\begin{tabular}{|c|c|c|c|c|c|c|c|c|c|c|c|c|c|c|c|c|c|c|c|}
\hline \multirow{3}{*}{ Subjects } & \multicolumn{16}{|c|}{ Test Results after Instruction } & & & \\
\hline & \multicolumn{4}{|c|}{ ubstitutes } & \multicolumn{6}{|c|}{ tibstitutes } & \multicolumn{6}{|c|}{ ubstitutes } & \multicolumn{3}{|c|}{ Errors } \\
\hline & (1) & $/ \mathrm{t} /$ & /s/ & /d/ & 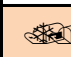 & p/t/ & $/ \mathrm{s} /$ & /d/ & $|z|$ & $/ \mathrm{m} /$ & Wo & नक्षस & $a+$ & en: & 12 & $\Rightarrow$ 网 & 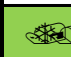 & $P$ arat & 2 \\
\hline S1 & & & & & 1 & & & & & & 2 & 2 & & & & & 0 & 1 & 4 \\
\hline S2 & 1 & 1 & & & 1 & 9 & & & & & 1 & & & & & & 2 & 10 & 1 \\
\hline S3 & & & & & 4 & & & & & & 4 & & & & & & 0 & 4 & 4 \\
\hline S4 & & & & & & & & 1 & & & 1 & & 1 & & & & 0 & 1 & 2 \\
\hline S5 & 1 & & & & & & & & & & & & & & & & 1 & 0 & 0 \\
\hline S6 & & & & & & & & & & & & & & & & & 0 & 0 & 0 \\
\hline S7 & 1 & & & & & & & & & & & & & & & & 1 & 0 & 0 \\
\hline S8 & & 1 & & & 2 & & & & & & 2 & 3 & & & & & 1 & 2 & 5 \\
\hline S9 & & & 1 & & 1 & & 2 & & 1 & & & & & & & & 1 & 4 & 0 \\
\hline S10 & & & & & 5 & 3 & & & & & 4 & 5 & & & & & 0 & 8 & 9 \\
\hline Totals & 3 & 2 & 1 & 0 & 14 & 12 & 2 & 1 & 1 & 0 & 14 & 10 & 1 & 0 & 0 & 0 & 6 & 30 & 25 \\
\hline & $50 \%$ & $33 \%$ & $17 \%$ & $0 \%$ & $47 \%$ & $40 \%$ & $7 \%$ & $3 \%$ & $3 \%$ & $0 \%$ & $56 \%$ & $40 \%$ & $4 \%$ & $0 \%$ & $0 \%$ & $0 \%$ & $4 \%$ & $20 \%$ & $17 \%$ \\
\hline & & & & & & & & & & & & & & & & & Total & Errors & $\begin{array}{c}61 \\
14 \%\end{array}$ \\
\hline
\end{tabular}




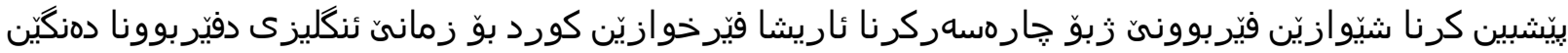

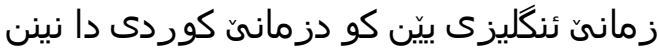

קֵوخته

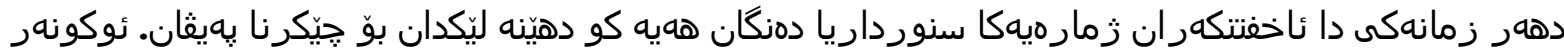

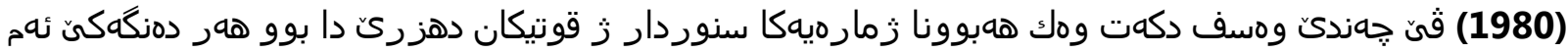

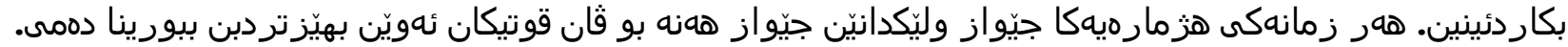

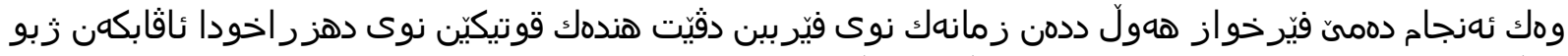

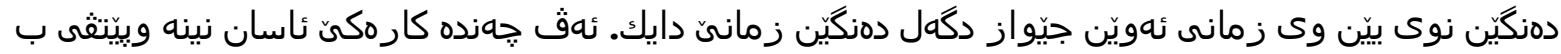

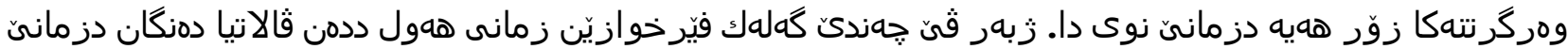

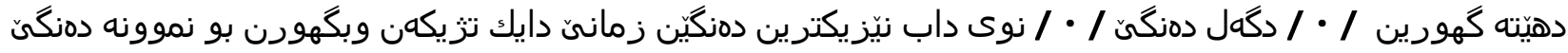

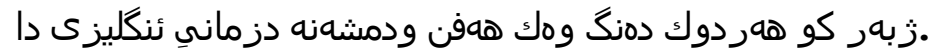

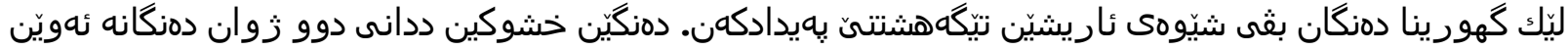

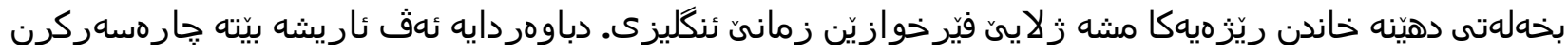

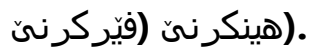

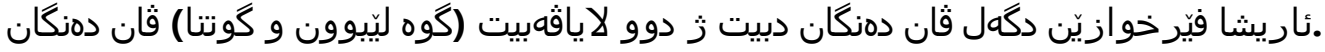

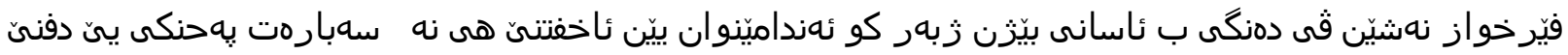

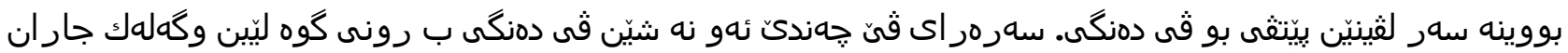

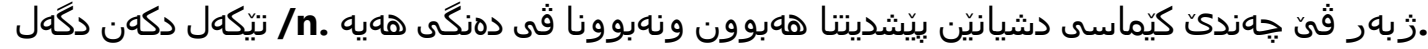

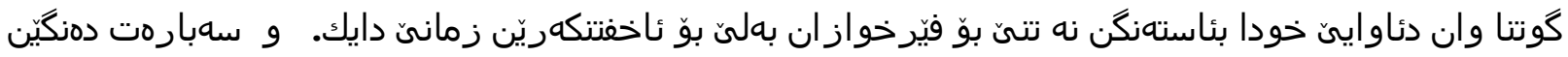

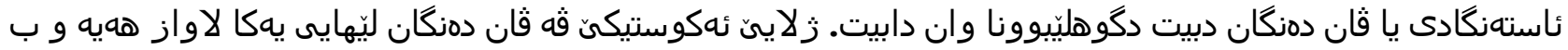

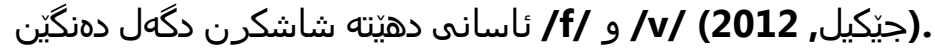

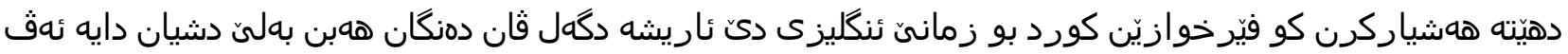

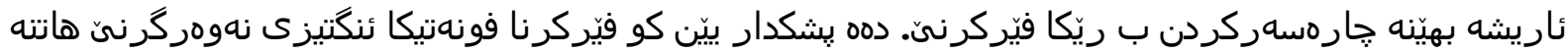

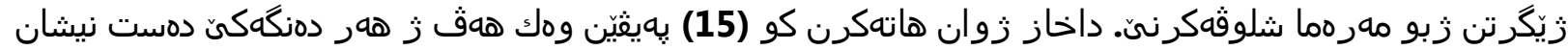

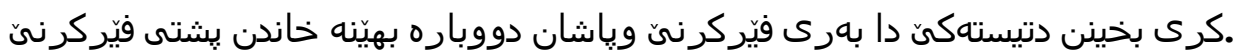

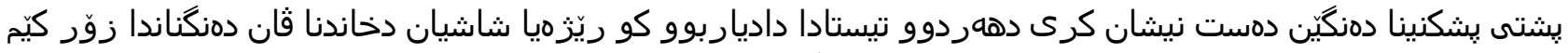

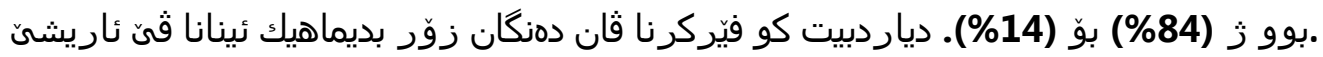

الخلاصة

يكون للمتكلمين في كل لغة أرقام ثابتة من وحدات الصوت, والتوت التي يتم جمعها لنتكون كلمات اللغة. يشبه

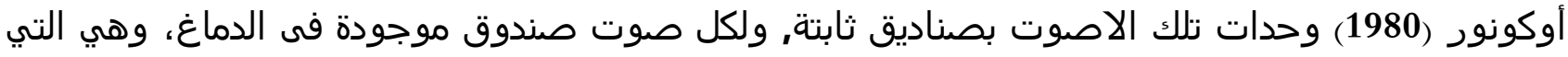

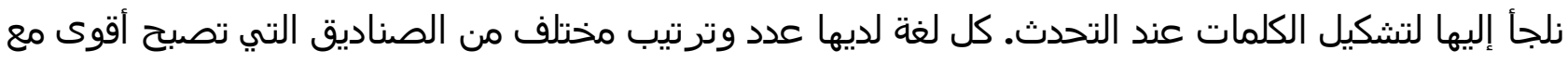

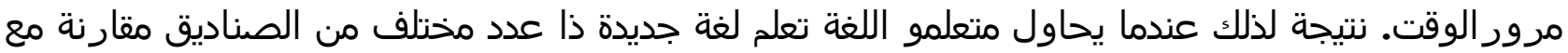




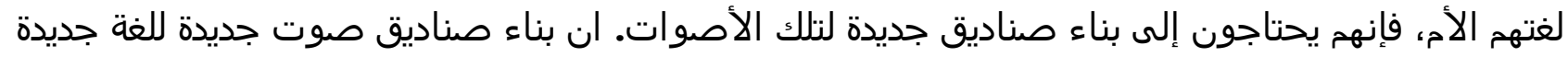

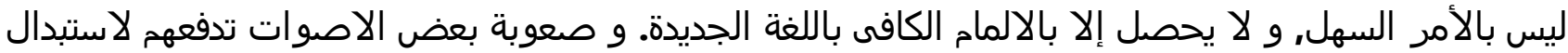

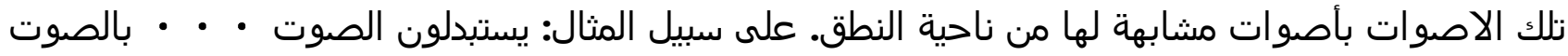

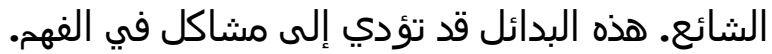

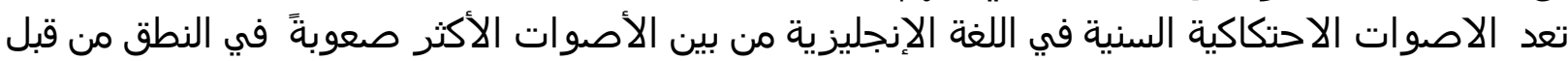

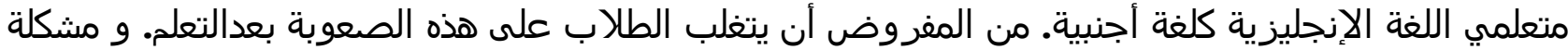

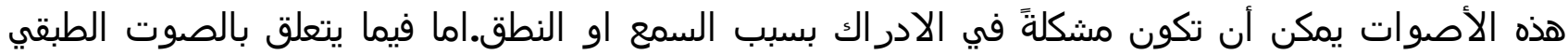

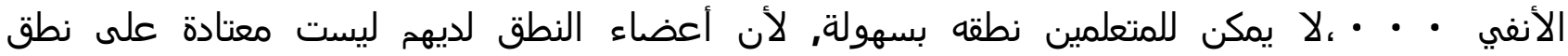

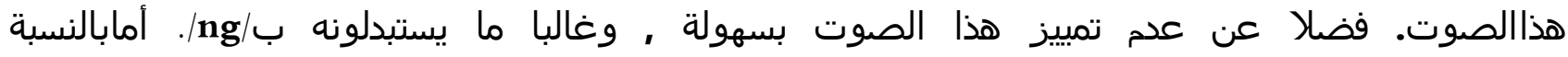

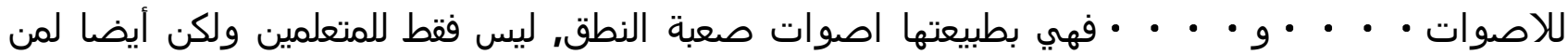

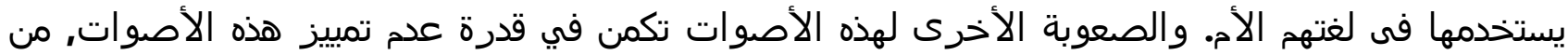
الناحية السمعية ،لكون هذه الأصوات ضعيفة إدراكيا ، ويمكن الخلط بسهولة فئلة بينها وبين /f/أو/إه/ (جيكيل،

من المفروض ان المتعلمين الكورد يواجهون صعوبة مع هذه الأصوات لعدم وجودها في اللغة الكردية.

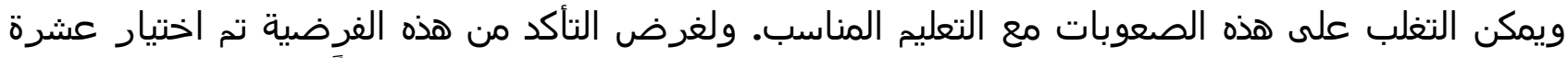

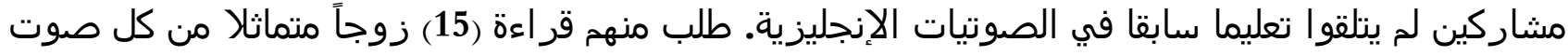
معني يتناقض مع أصوات مماثلة في اختبار ماقبل التعليم.

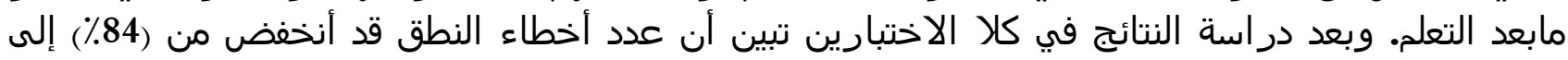
(14٪). النتائج تبين ان توفير التعليم القيم والفعال يساعد في التغلب على هذه الصعوبات. 